\title{
“COM DUAS GEJAS EM CADA UMA DAS FONTES": ESCARIFICAÇÕES E O PROCESSO DE TRADUÇÃO VISUAL DA diÁSPORA JEJE EM MiNAS GERAIS DURANTE O SÉCULO XVIII*
}

\author{
Aldair Rodrigues (D) \\ Universidade Estadual de Campinas
}

ste artigo analisa o processo de interpretação das marcas corporais
da população africana que viveu no distrito diamantino da
capitania de Minas Gerais em meados do século XVIII, com foco nos impactos da presença dos grupos de língua gbe na formação do léxico empregado no detalhamento de efeitos visuais das cicatrizes rituais: geja. Essa palavra foi empregada na descrição de pormenores das escarificações de 87 pessoas em um universo de 444 escravizados compreendidos pelos registros das matrículas de escravos realizadas entre 1753 e 1754, cujo administrador era José Álvares Maciel. ${ }^{1}$

* Pesquisa financiada com recursos do Prêmio Capes AUXPE 0382/2016, processo 23038.009186/2013-63. Sou imensamente grato às sugestões dos pareceristas anônimos que avaliaram este artigo, aos comentários de Ivana Stolze Lima, Natã Freitas, à gentileza das funcionárias da biblioteca Melville Herskovits (Northwestern University), Esmeralda Kale, Florence Mugambi e Crystal L. Martin, e ao apoio de meus amigos ichsianos Angelo Carrara e Jonis Freire.

1 Arquivo Público Mineiro (APM), Belo Horizonte, Casa dos Contos (CC), cód. 2.048, Matrícula de escravos (1753-1754), Tejuco, 1752. Em sua abertura, consta a seguinte informação: "O doutor intendente dos diamantes rubricará este livro fazendo-lhe sua abertura e encerramento e numerando na forma do estilo; o qual há de servir para se matricularem os negros do futuro contrato que há de principiar em o primeiro de janeiro de 1753, de que é administrador José Álvares Maciel. Tejuco, 2 de dezembro de 1752”. 
Desconhecida na língua portuguesa, os oficiais da intendência dos diamantes usaram a palavra geja sem jamais explicar seu significado, deixando implícito que o termo era amplamente conhecido no cotidiano da sociedade mineradora. Analisaremos sua emergência como índice de uma cadeia mais ampla de significados atrelados à etnogênese jeje em um contexto de grande concentração urbana de povos da Costa da Mina na região.

O objetivo deste artigo é inserir a realidade social de Minas Gerais no circuito mais amplo do mundo afro-atlântico por meio do diálogo com a sólida historiografia sobre a constituição histórica da nação jeje (povos do golfo do Benim falantes de línguas gbe) na Bahia e com os estudos sobre os contextos de escravização e deportação de grupos afro-ocidentais para o Brasil durante o século XVIII. Acreditamos que a ênfase na dimensão estética que permeava a classificação dos africanos por origem tem o potencial de revelar aspectos ainda pouco conhecidos da diáspora africana, em geral, e da diáspora gbe, em particular.

\section{Controle social e sinais de nação}

A cunhagem de termos que designavam a proveniência dos africanos e o uso de informações que pudessem singularizá-los estiveram no centro das políticas fiscais e das estratégias de controle social adotadas pela administração portuguesa na região mineradora. O regimento do imposto da capitação de 1735 já enfatizava a importância das “pátrias”, “alcunhas” e "sinais distintivos" como meio de diferenciar um escravizado de outro na documentação. ${ }^{2} \mathrm{O}$ sistema fiscal, embora tenha oscilado ao longo do tempo, era estruturado com base no número de escravizados, que, além de matriculados, deveriam portar comprovantes de matrícula, “bilhetes”, com seus respectivos dados.

2 Gomes Freire de Andrade, “Regimento da capitação, 1735” in Luciano Figueiredo (org.), Códice Costa Matoso (Belo Horizonte: Fundação João Pinheiro, 1999), p. 303. 
No caso do distrito diamantino, houve um acirramento dessa estratégia de controle porque a Coroa estabelecia um regime de monopólio da extração das pedras preciosas por meio da arrematação dos contratos. As cláusulas fixavam um limite para o número de escravizados que poderiam ser empregados nas jazidas abrangidas pelos arrematantes: 600 pessoas, sendo 400 para a demarcação do Tejuco e 200 para as minas dos Pilões, em Goiás, que fazia parte do mesmo contrato. ${ }^{3}$ Segundo Carrara, dessa documentação gerada pela burocracia fiscal dos diamantes, o códice referente à arrecadação dos anos 1753 e 1754, aqui em análise, é o único encontrado até agora da série "matrículas dos escravos". ${ }^{4}$

Naquele contexto, não bastava classificar os escravizados por suas origens, "nações” cada vez mais específicas, era requerido que o intendente dos diamantes e os escrivães examinassem seus corpos em busca de seus respectivos “sinais”. O Conselho Ultramarino havia determinado em 1743 que aquelas informações deveriam ser transcritas em formulários impressos, os “bilhetes”, que vinham de Lisboa. Após o registro, os bilhetes deveriam ser portados pelos escravizados para que fossem conferidos em caso de suspeita de fraude no contrato, sonegação fiscal e necessidade de autorização para substituição, em casos de doença, morte ou fuga. A descrição das escarificações permitia saber se a pessoa abordada havia sido matriculada ou não para o trabalho nas minas: "Porque é fatível que algum dos escravos capitados fuja, adoeça ou morra fugindo, serão obrigados os administradores ou feitores a dar, no termo de quarenta e

3 Anônimo, "História da Vila do Príncipe e do modo de lavar os diamantes e de extrair o cascalho, 1750” in Figueiredo (org.), Códice Costa Matoso, p. 848.

4 Angelo Carrara, "Desvendando a riqueza na terra dos diamantes", Revista do Arquivo Público Mineiro, v. 41 (2005), p. 46. Segundo o autor, “a partir de 1740, a extração dos diamantes começou a ser feita sob a forma de contratos, cuja primeira arrematação se deu a 10 de junho de 1739. Dito de outra forma, a atividade de extração passou a ser terceirizada a uma companhia particular que vencesse licitação aberta pela Real Fazenda. Os vencedores da licitação - contratadores - tinham o direito de empregar seiscentos escravos, cujos nomes deviam ser lançados em um livro destinado a esse fim. Sobre cada um, pagariam os contratadores a capitação anual de 23 mil réis, sendo-lhes proibido minerar com maior número. [...] Esse sistema perdurou até 1771” (p. 42). Sobre a capitação ver também: Andréa Lisly Gonçalves, As margens da liberdade, Brlo Horizonte: Fino Traço, 2011, pp 112-114. 
oito horas, conta ao intendente, com o nome e mais sinais do tal escravo". Além disso, deveria ser declarado "quem é seu senhor, para que as guardas dos dragões e as da mesma companhia o busquem". ${ }^{5}$

Era possível, pelas marcas rituais, saber se uma pessoa interpelada seria a mesma descrita no comprovante de matrícula que carregava e se seus dados batiam com aqueles registrados no cartório da intendência. No caso daqueles que não falavam português com fluência (muitos eram recém-chegados), as marcas adquiriam ainda mais importância para a identificação de alguém. Por meio das escarificações era viável também controlar os dias em que os escravizados não trabalhavam por estarem doentes, em tratamento no hospital do distrito. Essas informações eram inseridas nos livros de matrícula e nas margens das fichas referentes às pessoas que não pudessem entrar nas lavras. Evidentemente, se esse registro traria descontos nos impostos que eram pagos a partir da matrícula, seria do interesse dos contratadores manipular essas informações. Sancho de Andrade Castro e Lanções, intendente responsável pelas matrículas que serão analisadas neste artigo, sublinhava que a patrulha do governo do distrito diamantino também era encarregada de inspecionar os córregos e rios, dia e noite, para verificar se havia escravizados sem bilhete de capitação, a fim de coibir a extrapolação do cômputo previsto na arrematação do contrato. ${ }^{6}$

Os chamados oficiais da matrícula - escrivão, escrevente dos bilhetes, fiscal, meirinho etc. - nos deixam entrever que, paulatinamente,

5 Conselho Ultramarino, "Condições com que se rematou o segundo contrato da extração dos diamantes, 1743” in Figueiredo (org.), Códice Costa Matoso, p. 650 (grifo nosso). Manuscrito: APM, CC 1.048, fls. 179-183v, Condições com que se rematou o segundo contrato da extração dos diamantes, Lisboa, 1743.

6 Segundo o intendente Sancho de Andrade Castro e Lanções, a patrulha da região dos diamantes era formada por um tropa de oitenta soldados, com um capitão, dois alferes, um tenente e tantos "cabos de esquadra quantos se precisam para a divisão das patrulhas, e andam sempre de dia e de noite pelos ribeiros e corgos demarcados e por onde laboram os contratos, examinando se andam neles negros de mais dos concedidos, e sendo obrigados a darem ao contrato as guardas necessárias” Anônimo, "História da Vila do Príncipe e do modo de lavar os diamantes e de extrair o cascalho, 1750” in Figueiredo (org.), Códice Costa Matoso, p. 849. 
foram se familiarizando com as marcas corporais mais frequentes em cada grupo e elaborando esse processo em termos de "sinais de nação" e "sinais da sua terra". Em uma dimensão mais específica, por meio delas acreditavam ser possível definir ou confirmar suas procedências africanas: "sinais de sabarú”, “sinais de ladano”, "sinais de courano” etc. Essa leitura das escarificações e tatuagens está relacionada ao interesse dos portugueses em estabilizar os marcadores das origens africanas, construindo ideias de grupos, nações, a partir do cruzamento entre procedência e cicatrizes rituais. Trata-se de uma conceitualização bastante redutora dos múltiplos significados das modificações corporais africanas, pois a bibliografia e os próprios assentos das matrículas, quando observados atentamente, indicam que as escarificações poderiam variar enormemente dentro de um mesmo grupo classificado como uma "nação”. A categoria nação empregada no processo de classificação das origens africanas no Atlântico escravista era extremamente maleável e guardava uma ampla variedade de significados. Dependendo do contexto e do momento da vida de uma pessoa, a nação a que estava associada poderia designar topônimos de macroáreas da organização do tráfico; portos de embarque; reinos e impérios; microfiliações políticas; classificações linguísticas de diversos níveis; ou etnônimos que designavam identidades étnicas mais específicas e auto-adscrições. A categorização poderia oscilar de um subgrupo para o descritor genérico mais amplo e vice-versa. Essa polissemia era constituída em meio a uma ampla cadeia afro-atlântica de produção de conhecimento articulada por ladinos, intérpretes, marinheiros, missionários, agentes comerciais estabelecidos nas feitorias, traficantes, proprietários e pelos próprios africanos, cuja ação histórica interferia na construção dos sentidos da taxonomia sobre suas origens. Não se tratava de um processo unilateral e tampouco as nações possuíam significados primordiais que linearmente remontariam à África. Os contornos de seu campo semântico eram definidos historicamente no contexto das relações sociais em que havia a presença africana. ${ }^{7}$

7 Esta definição foi baseada em: Mariza Soares, “A 'nação' que se tem e a 'terra' de onde se vem: categorias de inserção social de africanos no Império português, século 
Na África, de forma muito sintética, podemos afirmar que as marcas rituais funcionavam como índices biográficos, uma vez que, em diferentes momentos da vida de uma pessoa, registravam na pele as dimensões da sua inserção no cosmos, marcavam ritos de passagem, mediavam a relação com a ancestralidade e expressavam lugares na vida social e política (coletividade familiar, clã e etnia). Elas poderiam ainda exteriorizar o histórico de saúde de uma pessoa (as marcas relacionadas às práticas profiláticas e terapêuticas); exprimir suas realizações pessoais (principalmente em contextos de conflitos militares, por exemplo); as posições nas relações de gênero; e perdas de familiares. Do ponto de vista mais subjetivo, havia margem para escolha dos desenhos ligados às práticas de embelezamento. A localização das marcas no corpo e sua nomenclatura tendia a estar de acordo com esses diferentes propósitos subjacentes a sua feitura. Ao longo da vida de uma pessoa, várias marcas poderiam ser adicionadas. ${ }^{8}$ Isto significa que os registros do arquivo

XVIII”, Estudos Afro-Asiáticos, v. 2 (2004), pp. 303-330; Juliana Barreto Farias, Carlos Eugênio Líbano Soares e Flávio dos Santos Gomes, No labirinto das nações: africanos e identidades no Rio de Janeiro, Rio de Janeiro: Arquivo Nacional, 2005; Eduardo Paiva, Dar nome ao novo: uma história lexical da Ibero-América, entre os séculos XVI e XVIII (as dinâmicas de mestiçagens e o mundo do trabalho), Belo Horizonte: Autêntica, 2015; Luis Nicolau Parés, A formação do candomblé: história e ritual da nação jeje na Bahia, Campinas: Editora da Unicamp, 2006, pp. 23-62; Douglas B. Chambers, "Ethnicity in the Diaspora: The Slave-Trade and the Creation of African 'Nations' in the Americas", Slavery \& Abolition, v. 22, n. 3 (2001), pp. 25-39; Lorand Matory, “Jeje: repensando nações e transnacionalismo”, Mana, v. 5, n. 1 (1999), pp. 57-80; Renato Silveira, "Nação africana no Brasil escravista: problemas teóricos e metodológicos”, Afro-Ásia, n. 38 (2008), pp. 245-301.

8 Esta breve síntese foi elaborada a partir de: Olatunji Ojo, "Beyond diversity: women, scarification, and Yoruba identity”, History in Africa, v. 35 (2008), pp. 347-374; Katrina Keefer, "Scarification and identity in the liberated Africans department register, 1814-1815”, Canadian Journal of African Studies, v. 47, n. 3 (2013), pp. 537-553; Henry Drewal, "Beauty and being: aesthetics and ontology in Yoruba body art" in Arnold Rubin (ed.), Marks of civilization: artistic transformations of the human body (Los Angeles: Museum of Cultural History University of California, 1988), pp. 83-96; Katrina Keefer, “Group Identity, Scarification, and Poro among Liberated Africans in Sierra Leone, 1808-1819”, Journal of West African History, v. 3, n. 1 (2017), pp. 1 25; Paul Lovejoy, "Scarification and the loss of history in the African diaspora" in Andrew Apter e Lauren Derby (orgs.), Activating the Past: History and Memory in the Black Atlantic World (Cambridge: Cambridge Scholars, 2010), pp. 99-138. 
colonial, no máximo, oferecem uma descrição do estágio das escarificações no momento em que os africanos foram deportados para o Brasil.

Além disso, na África, os padrões dos desenhos formados pelas incisões poderiam sofrer transformações em contextos de contatos culturais e interétnicos ligados a trocas comerciais, migrações e deslocamentos causados por guerras e fenômenos diversos. Portanto, as concepções coloniais em torno dos "sinais de nação" congelavam e simplificavam as muitas camadas que constituíam a semântica das modificações corporais, sobretudo escarificações e tatuagens.

No distrito diamantino, as informações sobre as escarificações eram obtidas por meio de uma violenta inspeção dos corpos dos africanos. Além das marcas faciais, os oficiais da matrícula detalham os sinais presentes em abdomens, peitos e costas, indicando que os escravizados ficavam despidos pelo menos até a cintura no momento das matrículas. ${ }^{9}$ A maioria das palavras utilizadas para caracterizá-las eram: lanho, sinal, risco, grelha, malha e geja. Quanto ao efeito visual, indicavam que os cortes seriam: lavrados, riscados, picados, retalhados etc. As escarificações e tatuagens são listadas juntamente com outras marcas que pudessem distinguir os escravizados, tais como cicatrizes, por exemplo, "cicatriz de porrete". ${ }^{10}$ No caso dos crioulos, eles não traziam escarificações no rosto, pois, segundo Lovejoy, não deram continuidade às práticas de escarificação nas Américas em razão do uso para controle social e das rupturas nos contextos que davam significados às escarificações, como linhagens e hierarquias sociais, por exemplo. ${ }^{11}$ Nas matrículas, as marcas de varíola eram instrumentalizadas para distinguir os indivíduos. Foi esse o caso de

9 Este aspecto era parte de um processo mais amplo de racialização dos africanos com base na leitura ideológica de seus corpos. A análise sobre esta dimensão encontra-se inserida em: Aldair Rodrigues, "African body marks, stereotypes and racialization in eighteenth-century Brazil”, Slavery \& Abolition, 2020, pp. 1-30 बiol.

10 APM, CC 2.048, n. 56, fl. 28v, Matrícula de João Ladá, que tinha "cicatriz de porrete na cabeça por cima da orelha direita”, Tejuco, 1752.

11 Lovejoy, "Scarification and the Loss of History". 
José crioulo, que era diferenciado de outros por ser "picado de bexigas e a barba sumida para dentro". ${ }^{12}$

Quanto aos carimbos do tráfico resultantes da violenta aplicação de ferro em brasa na pele dos africanos, encontramos raríssimos registros na documentação setecentista. O caso da matrícula de João Benguela, que era "liso da cara com uma coroa em cima de um -R- no peito direito" é um deles. ${ }^{13} \mathrm{O}$ carimbo indica que os traficantes haviam pago o imposto de exportação à Coroa portuguesa antes de João ser embarcado em Angola. Os grupos da África ocidental analisados neste artigo não apresentam marcas desse tipo, mas a documentação produzida na Costa da Mina indica que havia esporadicamente a aplicação de "marcas da carregação" em parte dos escravizados embarcados em Ajudá. Elas variavam conforme o traficante. ${ }^{14}$ Em geral, é provável que essa prática fosse mais sistemática nos portos da África portuguesa, onde a Coroa tinha domínio territorial com aparato fiscal sob seu controle e impunham o batismo aos africanos antes dos navios partirem para o Brasil, como explicam Alencastro, Candido e Ferreira. ${ }^{15}$

12 APM, CC 2.048, n. 137, fl. 69, Matrícula de escravos, Tejuco, 1752. Embora este seja um tema que ainda careça de pesquisas aprofundadas, não podemos inferir que as escarificações tenham desaparecido completamente entre as práticas culturais dos afrodescendentes nascidos no Brasil. É possível que, passando por transformações, fossem utilizadas em rituais de cura e iniciação religiosa.

13 APM, CC 2.048, n. 366, fl. 183v, Matrícula de escravos, Tejuco, 1752.

14 AHU, São Tomé, cx. 9, doc. 944, fls. 15v 16, Contas da carregação, Costa da Mina, 1752. Ver também: Suely Cordeiro de Almeida, "Rotas Atlânticas: o comércio de escravos entre Pernambuco e a Costa da Mina (c.1724-c.1752)”, História (São Paulo), v. 37 (2018), p. 26.

15 Luiz Felipe de Alencastro, O trato dos viventes: formação do Brasil no Atlântico Sul, São Paulo: Companhia das Letras, 2000, pp. 180-184; Mariana Candido, An African Slaving Port and the Atlantic World: Benguela and Its Hinterland, Cambridge: Cambridge University Press, 2013, pp. 450-454; Roquinaldo Ferreira, Cross-cultural exchange in the Atlantic World: Angola and Brazil during the Era of the Slave Trade, Cambridge: Cambridge University Press, 2012, p. 122. Luciano Figueiredo localizou e publicou o fac-símile de um códice do Arquivo Nacional que demonstra o uso das marcas do tráfico nos registros dos escravizados emancipados pela comissão mista anglo-brasileira entre 1839 e 1841, cf. Luciano Figueiredo (org.), Marcas de escravos: listas de escravos emancipados vindos a bordo de navios negreiros (1839-1841), Rio de Janeiro: Arquivo Nacional; Ministério da Justiça, 1989. Para um análise abrangente sobre o uso de marcas no tráfico, 
Na descrição das figuras formadas pelas escarificações, o escrivão da intendência costumava delinear tamanho; extensão; textura; número e simetria ou não dos desenhos na sua distribuição em relação às duas metades do corpo; estabelecia analogias com, por exemplo, grelhas, círculos, estrelas, meias-luas, riscos, flores, armas (espada ou lança) e animais (cobras). O corpo era lido e interpretado como um repositório de semelhanças, diferenças e singularidades a ser potencialmente acionado para a recuperação das informações envolvendo transações tributárias centralizadas na propriedade escrava.

Na nomeação meticulosa de todos esses detalhes, nos deparamos com o fenômeno extraordinário e intrigante que é o uso da palavra geja no detalhamento das marcas de 87 pessoas num universo de 444 escravizados compreendidos pelo contrato referente ao período entre 1753 e 1754. Luís Mendonça Cabral foi o escrivão que atuou como principal responsável pela confecção dos registros das matrículas deste códice. Informações de 1764, presentes no seu processo de habilitação para ser armado cavaleiro da Ordem de Cristo, indicam que quando atuou nas matrículas aqui em análise já fazia mais de uma década que trabalhava na produção de documentação deste tipo, exercendo vários ofícios na fazenda real. Ele havia nascido em Portugal no ano de 1717 na Vila de Trancoso, onde seu pai era juiz de fora, e passou ao Brasil em 1739. Logo que chegou assumiu por um tempo o posto de provedor do registro fiscal de Paraibuna no Caminho Novo, por onde transitavam muitos escravizados levados para as minas. Logo depois passou ocupar os cargos de escrivão na intendência de Vila Rica e, aparentemente por um intervalo curto, em Mariana, de onde foi finalmente transferido para a intendência dos diamantes no arraial do Tejuco no início da década de 1750, não sendo possível precisar a data exata em que isto ocorreu. ${ }^{16}$

consultar: Katrina Keefer, "Marked by fire: brands, slavery, and identity”, Slavery \& Abolition, v. 40, n. 4 (2019), pp. 659-681 ब요.

16 Arquivo Nacional da Torre do Tombo (ANTT), Lisboa, Habilitações da Ordem de Cristo, letra L, mç. 6, n. 5, 1764-1765. 
Ao chegar ao Tejuco, Cabral já devia estar bastante familiarizado com o universo escravista de Minas Gerais. Nas matrículas para o biênio 1753-1754, ele grafou o termo geja de uma única forma em todos os registros. Já no caso de substituição do primeiro matriculado em decorrência de fuga ou morte, notamos que houve duas ocorrências no ano de 1753 em que a grafia oscilou para geija nas mãos de um segundo escrivão cujo nome nos escapa. Uma delas foi a matrícula número 28 , de Francisco Nagô, que em razão de sua fuga foi substituído por "Vicente Nagô com uma geija entre as sobrancelhas, duas em cada fonte e uma em cada face, idade 18 anos, avaliado em 220.000", em 3 de julho de $1753 .{ }^{17}$ Em termos globais, no primeiro rol das matrículas do códice, foram listadas 396 pessoas e, com a sucessão de fugas e falecimentos, houve um total de 48 substituições. Nesses casos, o número da ficha não sofria alterações, os dados referentes aos substitutos eram inseridos na mesma folha em que aparecia a descrição do primeiro matriculado.

Os vocabulários da língua portuguesa produzidos no Antigo Regime (o Vocabulário de Raphael Bluteau da década de 1720, e o dicionário de Antônio de Moraes Silva de 1789) e os dicionários contemporâneos não fazem qualquer menção a geja, nem nas entradas e nem nos textos dos verbetes. Tampouco o escrivão e os agentes coloniais se deram ao trabalho de definir seu sentido no século XVIII, indicando que o termo era amplamente difuso na região diamantina e os potenciais usuários da documentação entendiam seu significado. Neste artigo, interessa analisar as dinâmicas subjacentes à emergência da palavra geja na documentação, delimitar os contornos e as nuances dos seus significados e as dinâmicas sociais que lhes davam inteligibilidade no âmbito das conexões entre o Brasil e o Golfo do Benim.

17 APM, CC 2.048, n. 28, fl. 14v, Matrícula de escravos, Tejuco, 1752 (grifo nosso). Nas substituições, as gejas aparecem em apenas dois casos. Neste caso, “fonte” significa têmpora. 


\section{A preponderância gbe no distrito diamantino e suas conexões com a Costa da Mina}

Os dados das matrículas mostram que os grupos da Costa da Mina perfaziam a esmagadora maioria das pessoas levados à força para o distrito diamantino; constituíam 74\% das 444 pessoas matriculadas, todos homens (Quadro 1).

Quadro 1

Origens da população matriculada (1753-1754)

\begin{tabular}{|c|c|c|c|}
\hline Macrorregião & Nação & Número & Com gejas \\
\hline \multirow{18}{*}{ África Ocidental } & Amol Mina & 1 & 0 \\
\hline & Ayono & 1 & 0 \\
\hline & Barba & 7 & 1 \\
\hline & Cabo Verde & 8 & 0 \\
\hline & Chambá & 11 & 0 \\
\hline & Clavari & 9 & 0 \\
\hline & Cobu & 19 & 5 \\
\hline & Coura/ Courano & 27 & 7 \\
\hline & Dagomé & 2 & 1 \\
\hline & Dama & 1 & 0 \\
\hline & Fom/ Fam & 36 & 7 \\
\hline & Gana[em] & 1 & 0 \\
\hline & Geja & 1 & 0 \\
\hline & Jaqueno & 1 & 1 \\
\hline & Ladá & 35 & 28 \\
\hline & Malê & 3 & 0 \\
\hline & Maqui/ Magui & 5 & 0 \\
\hline & Mina & 10 & 4 \\
\hline
\end{tabular}


Quadro 1 - continuação

\begin{tabular}{|c|c|c|c|}
\hline & Mina alemão & 1 & 0 \\
\hline & Nagô & 60 & 8 \\
\hline & Oheme/ Veme & 18 & 11 \\
\hline & Sabarú & 60 & 5 \\
\hline & São Tomé & 1 & 0 \\
\hline & Tapa & 10 & 0 \\
\hline & Timbú & 1 & 0 \\
\hline & Ussa [Haussá] & 1 & 0 \\
\hline & Subtotal & 330 & 78 \\
\hline \multirow{10}{*}{$\begin{array}{c}\text { África } \\
\text { Centro-ocidental }\end{array}$} & Angola & 20 & 0 \\
\hline & Benguela & 51 & 3 \\
\hline & Congo & 14 & 2 \\
\hline & Ganguela & 7 & 3 \\
\hline & Luanda & 2 & 1 \\
\hline & Massangano & 4 & 0 \\
\hline & Monjolo & 3 & 0 \\
\hline & Mulato de Angola & 1 & 0 \\
\hline & Rebolo & 1 & 0 \\
\hline & Subtotal & 103 & 9 \\
\hline \multirow{2}{*}{ África Oriental } & Moçambique & 1 & 0 \\
\hline & Subtotal & 1 & \\
\hline \multirow{5}{*}{$\begin{array}{c}\text { África } \\
\text { (desconhecido) }\end{array}$} & Mavul & 1 & 1 \\
\hline & Dossu & 1 & 0 \\
\hline & Fanjico & 1 & 0 \\
\hline & Amagu & 1 & 0 \\
\hline & Subtotal & 4 & \\
\hline \multirow{3}{*}{ Brasil } & Cabra & 1 & 0 \\
\hline & Crioulo & 5 & 0 \\
\hline & Subtotal & 6 & 0 \\
\hline \multicolumn{2}{|c|}{ Total } & 444 & 87 \\
\hline
\end{tabular}

Fonte: APM, CC 2.048, Matrícula de escravos, Tejuco, 1752. 
A exploração das jazidas diamantíferas nesta porção norte da capitania de Minas Gerais a partir da década de 1730 coincide com o estabelecimento da hegemonia do reino do Daomé na região da Baía do Benim e com o auge da afirmação do porto de Ajudá como o epicentro do tráfico na Costa da Mina. Originalmente localizado no interior, com capital em Abomé a cerca de 100 km do litoral, na década de 1720 o então rei daomeano Dossou Agadja liderou um processo de expansão em direção ao litoral e passou a controlar o fornecimento de escravizados nos seus principais portos até meados do século XVIII. Nessa época, Porto Novo, a leste e fora de seu controle, estava emergindo como terminal importante em reação ao afã monopolista do rei daomeano. ${ }^{18}$

As dinâmicas que conectavam a Costa da Mina e o Brasil ganharam mais densidade analítica nos últimos anos a partir da consolidação do banco de dados do tráfico, de um lado, e dos dados sobre a composição étnica da população escravizada extraídos dos arquivos brasileiros. Com base nas informações disponíveis na bibliografia e no Trans-Atlantic Slave Trade Database, Silva Júnior resume que foram deportadas 480.836 pessoas do Golfo do Benim entre 1700 e 1730, a maioria delas pelo porto de Ajudá. ${ }^{19}$

O tabaco produzido no sul da Bahia e o ouro em pó de Minas Gerais desempenhavam papel fundamental para a aquisição de escravizados naquela zona; ${ }^{20}$ e o porto de Salvador funcionava como seu principal local de desembarque no Brasil, onde aportaram $80 \%$ do total

18 Para uma síntese desse processo, consultar: Robin Law, The Slave Coast of West Africa 1550-1750: The Impact of the Atlantic Slave Trade on an African Society, Oxford: Clarendon, 1991; Robin Law, The kingdom of Allada, Leiden: CNWS, 1997; I. Akinjogbin, Dahomey and its neighbours, 1708-1818, Cambridge: Cambridge University Press, 1967; Carlos da Silva Júnior, "Interações atlânticas entre Salvador e Porto Novo (Costa da Mina) no século XVIII”, Revista de História, n. 176 (2017), pp. 1-41.

19 Carlos da Silva Júnior, “Ardras, minas e jejes, ou escravos de 'primeira reputação': políticas africanas, tráfico negreiro e identidade étnica na Bahia do século XVIII”, Almanack, n. 12 (2016), pp. 6-33, p. 21. Consultar também: Edna G. Bay e Kristin Mann (orgs.), Rethinking the African Diaspora: the Making of a Black Atlantic World in the Bight of Benin and Brazil, Leiden: Taylor and Francis, 2001.

20 Pierre Verger, Fluxo e refluxo do tráfico de escravos entre o Golfo do Benin e a Bahia de todos os Santos dos séculos XVII a XIX, 2a ed., Salvador: Corrupio, 1987. 
de trazidos para o território colonial. ${ }^{21}$ Parte expressiva deles era depois acorrentada e levada para Minas, sobretudo até meados do século XVIII, por meio da terceira perna do tráfico. ${ }^{22}$ Ribeiro estimou que, entre 1728 e 1748, 40\% dos africanos que chegavam à Bahia eram redistribuídos para a zona mineradora, percentual que diminuiu expressivamente nos decênios seguintes. Parte deles, era enviada por caminhos terrestres e por via marítima até o Rio de Janeiro, de onde seguiam para as minas. No intervalo entre 1739 e 1759, a Bahia remetia uma média anual de 2.100 pessoas para Minas Gerais, ao passo que o Rio de Janeiro já enviava 3.900. Na década de 1760, o percentual de redistribuição baiana caiu para $18 \%$, com média anual de 882 pessoas. ${ }^{23}$

Essa mudança tem a ver com a consolidação do Caminho Novo na década de 1730, que possibilitou ligar as minas diretamente ao Rio. Isso, junto com dinâmicas internas do continente africano, contribuiu para que Angola superasse a África Ocidental como principal macrorregião de origem da população africana da capitania mineradora a partir de meados da centúria. ${ }^{24}$ Ainda assim, é importante sublinhar que a preponderância adquirida pelo Caminho Novo não significou um ostracismo das rotas do

21 Silva Júnior, “Ardras, minas e jejes”, p. 23.

22 Alexandre Vieira Ribeiro, "A cidade de Salvador: estrutura econômica, comércio de escravos, grupo mercantil (c.1750-c.1800)”, Tese (Doutorado em História), Universidade Federal do Rio de Janeiro, Rio de Janeiro, 2009, p. 362.

23 Ribeiro, “A cidade de Salvador", p. 51. Uma pequena parte dos escravizados levados para a Minas Gerais era desembarcada em Pernambuco.

24 Segundo Carrara, em 1729, o valor da arrematação do contrato dos Caminhos Novo e Velho superou o valor relativo ao contrato do Caminho do Sertão da Bahia e Pernambuco: o primeiro, no valor de 5 arrobas, 13 libras, 110 oitavas e 64 grãos; o segundo, a 5 arrobas, 12 libras, 77 oitavas e 30 grãos. Cerca de três décadas mais tarde, em 1755, entraram pelo Caminho Novo 3.549 escravos, ao passo que apenas 510 entraram pelo Caminho Velho e pelo Caminho do Sertão. Angelo Carrara, Minas e currais: produção rural e mercado interno em Minas Gerais, 1674-1807, Juiz de Fora: Editora UFJF, 2007, pp. 119-121. Sobre a relação entre os caminhos, o comércio e a colonização da capitania, consultar: Renato Pinto Venâncio, "Comércio e fronteira em Minas Gerais colonial” in Júnia Ferreira Furtado (org.), Diálogos oceânicos, Minas Gerais e as novas abordagens para uma história do Império Ultramarino Português, (Belo Horizonte: Editora UFMG, 2001), pp. 180-192; Isnara Pereira Ivo, Homens de Caminho: trânsitos culturais, comércio e cores nos sertões da América portuguesa - Século XVIII, Vitória da Conquista: Edições Uesb, 2012. 
tráfico que vinham da Bahia pelos sertões, margeando o rio São Francisco, elas permaneciam sendo relevantes para as comarcas do Rio das Velhas e principalmente do Serro Frio, onde estava o distrito diamantino, como mostram dados analisados por Furtado com base em livros de batismos. ${ }^{25}$

Na Costa da Mina, conforme a documentação do Conselho Ultramarino, a palavra "geja” aparece como uma nação e ela estava entre as preferidas pelos traficantes baianos. Silva Júnior localizou um memorial redigido por Gaspar Pinheiro da Câmara Manoel, em 1766, indicando que, entre os africanos embarcados para o Brasil, havia aqueles de "primeira reputação como ardas, gejas e ainda os minas”. ${ }^{26}$ Considerando o contexto de produção do documento, é possível depreender que os afro-ocidentais cujas origens eram classificadas como nação geja estavam sendo deportados principalmente pelo porto de Ajudá, um dos principais da Costa da Mina na primeira metade do Setecentos. Gaspar contrapunha os portos tradicionais daquela costa, de onde saíam os gejas, aos terminais situados mais a leste, na região de Benim e Calabar, onde escravizados poderiam ser adquiridos por preços mais baixos, em meados da década de 1760 .

Inferimos então que o termo geja utilizado em Minas Gerais para fazer referência às escarificações é uma variação da grafia da palavra gege (e posteriormente, jeje), amplamente conhecida na Bahia como uma nação que funcionava como termo guarda-chuva para abranger os grupos da Baía do Benim que eram falantes das línguas gbe (fon, ewe, gun, mahi, mina etc.), pertencentes, ao lado de outros idiomas da África Ocidental, à família linguística cuá. ${ }^{27}$ Os trabalhos de Sogbossi e Castro,

25 Júnia Ferreira Furtado, “Teias de negócios: conexões mercantis entre as Minas do ouro e a Bahia, durante o século XVIII” in João Fragoso, Manolo Florentino, Antonio Carlos Jucá de Sampaio e Adriana Pereira Campos (orgs.), Nas rotas do Império: eixos mercantis, tráfico e relações sociais no mundo português (Vitória: Edufes, 2006), pp. 165-192. Ribeiro, “A cidade de Salvador”.

26 AHU, Conselho Ultramarino, São Tomé, cx. 10, doc. 93, Carta de Gaspar Pinheiro da Câmara Manoel para o Conselho Ultramarino, Lisboa, 15 out. 1766, apud Silva Júnior, “Ardras, minas e jejes”, p. 12 (grifo nosso).

27 Ewe e fon são as línguas majoritárias e possuem parentesco histórico-genético. Gbe, nessas línguas, seria, segundo Castro, o “lexema comum para dizer 'língua, idioma””. Cf. Yeda Castro, A língua mina-jeje no Brasil: um falar africano em Ouro Preto do 
influenciados pelo linguista Hounkpati B. Christophe Capo, informam que esses idiomas, que guardavam variados níveis de intercompreensão entre si, eram falados por uma diversidade de grupos étnicos que viviam na zona que, grosso modo, se estende do rio Volta à fronteira do atual Benim com a Nigéria: os anló, agonli, aizô, tchi, ewe, mina, fon, gun, huedá, hula, cotafon, mahi, tofin, tori, uatchi e uemé (Figura 1). Em sua maioria, esses grupos narram suas origens em Adjá Tado, no atual Togo. ${ }^{28}$

Figura 1

Área dos gbe-falantes e principais grupos étnicos

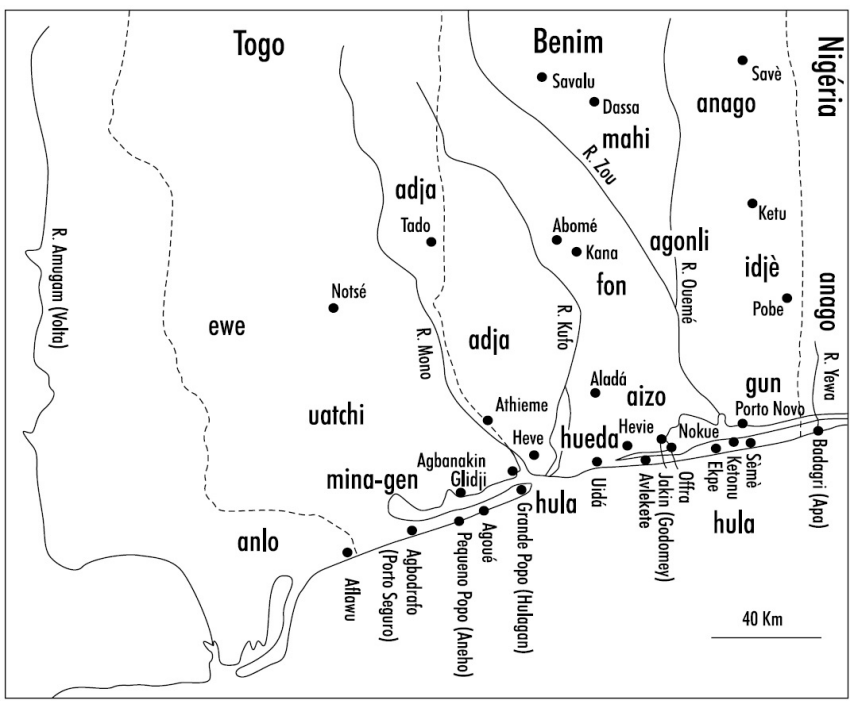

Fonte: Parés, A formação do candomblé, p. 30.

século XVIII, Belo Horizonte: Fundação João Pinheiro; Secult-MG, 2002, p. 54. Sobre essa questão, consultar também: Matory, “Jeje: repensando nações e transnacionalismo”. O conceito de guarda-chuva étnico, tal como utilizado aqui, foi desenvolvido por João Reis ao analisar as lógicas abrangentes por trás da classificação das origens africanas pelos senhores de escravos. Por exemplo, ver: João José Reis, “Identidade e diversidade étnicas nas irmandades negras no tempo da escravidão”, Tempo, v. 2, n. 3 (1997), pp. 7-33.

28 Castro, A língua mina-jeje no Brasil, p. 47; Hippolyte Brice Sogbossi, La tradición ewé-fon en Cuba: contribución al estúdio de la tradición ewé-fon (arará) en los pueblos de Jovellanos, Perico y Agramonte, Cuba, Havana: Fundação Fernando Ortiz, 1998. 
Parés salienta que nessa região havia um cosmopolitismo expresso, por exemplo, no multilinguismo e nas interações culturais entre vários grupos étnicos por meio de migrações ligadas a crises políticas, e no intenso intercâmbio com os vizinhos iorubás a leste. ${ }^{29} \mathrm{Na}$ Bahia, essa experiência pretérita marcada pelo compartilhamento de elementos culturais comuns influenciou a formação histórica da "nação jeje”, que se consolidou na segunda metade do século XVIII como uma identidade coletiva propiciada pela "progressiva chegada de escravos gbe-falantes" na primeira metade da centúria, sobretudo entre 1700 e 1730 . A primeira ocorrência documental da presença jeje na Bahia, grafada como gege, data de $1711 .^{30}$

\section{Geja como nação e geja como marca corporal}

Diferentemente do que acontecia na Bahia, em Minas Gerais jamais houve uma generalização de geja - ou suas variações gege ou jeje como nomenclatura de nação de origem para a população gbe da Costa da Mina. O termo abrangente que esteve mais próximo de desempenhar esse papel foi “mina” (nação mina), embora ali ele funcionasse também como descritor da macroárea África Ocidental, em contraposição à África Centro-ocidental, englobando outros grupos minoritários afro-ocidentais, como os iorubás, os povos da Senegâmbia e da Baía de Biafra. ${ }^{31}$

Nas matrículas, encontramos apenas um único registro em que geja foi listada como uma nação. Trata-se da ficha 225 referente a "Lucas de nação geja de idade de 40 anos, com uma cicatriz grande na face direita e outras no pescoço da parte esquerda, avaliado em 120\$000r”. ${ }^{32}$ Embora

29 Parés, A formação do candomblé, pp. 23-62.

30 Parés, A formação do candomblé, p. 47 e p. 53.

31 Aldair Rodrigues, "Quem eram as negras e os negros minas da capitania de Minas Gerais no século XVIII” in Ivana Stolze Lima, Juliana Farias e Aldair Rodrigues (orgs.), A diáspora mina: africanos entre Brasil e o Golfo do Benim (Rio de Janeiro: Nau, 2020), pp. 317-352.

32 APM, CC 2.048, n. 225, fl. 113, Matrícula de escravos, Tejuco, 1752 (grifo nosso). 
única, essa matrícula indica que a grafia “geja” com o significado de nação era exatamente a mesma empregada na especificação das marcas corporais, conforme podemos verificar na Figura 2.33

Figura 2

Nação geja e escarificação geja

a) "Lucas de nação geja”

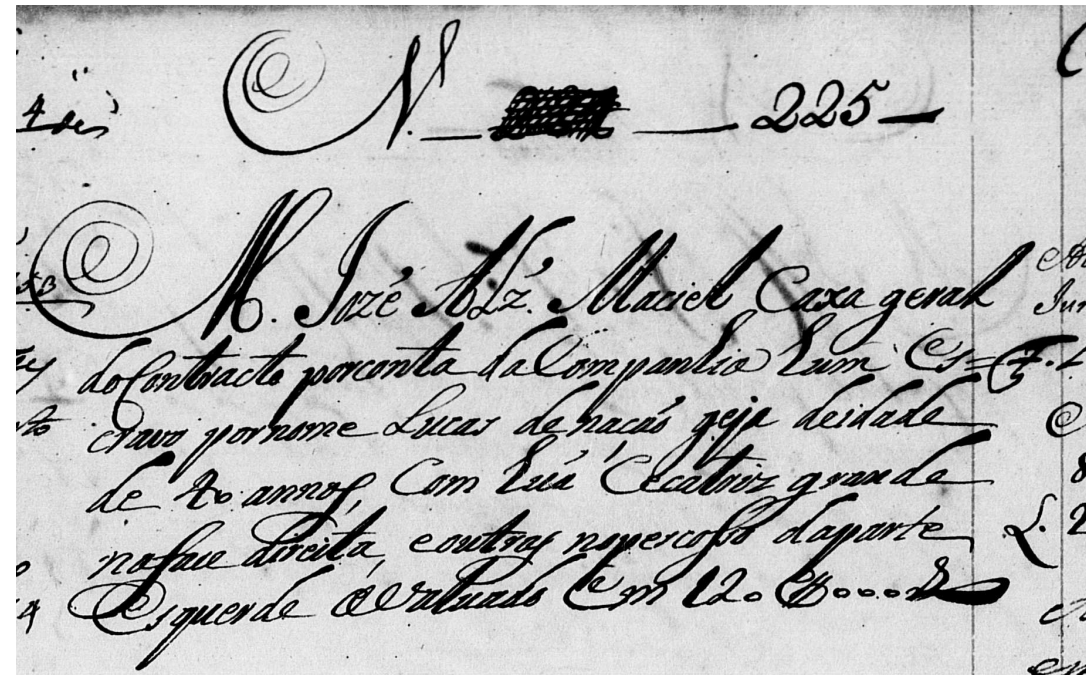

Detalhe: "nação geja"

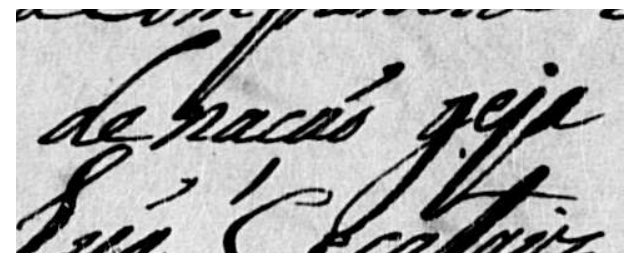

33 A única sutileza é que geja enquanto marca corporal variava em número (geja/gejas) e era modificada por adjetivos que poderiam lhe caracterizar (grande, comprida, pequena, levantada). 
b) "com uma geja em cada uma das faces e outra no cimo do nariz e uma cicatriz no canto da sobrancelha esquerda”

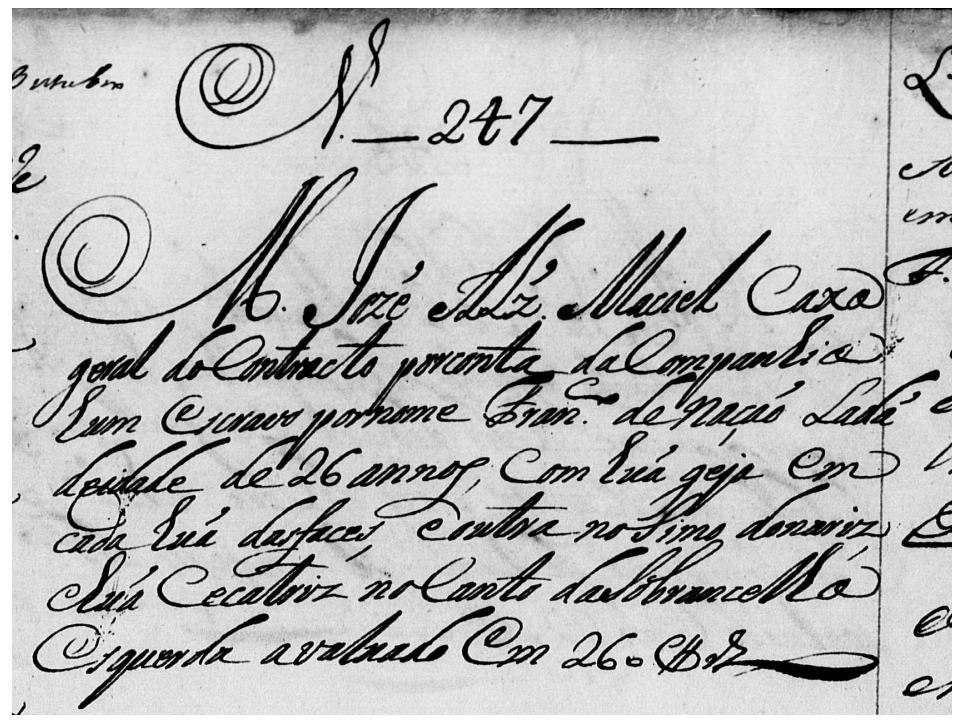

Detalhe: "com uma geja”

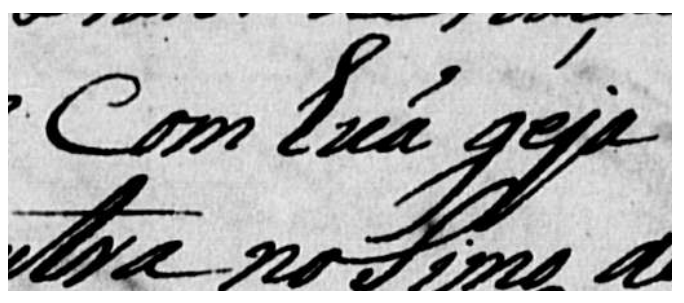

Fonte: a) APM, CC 2.048, n. 225, fl. 113, Matrícula de escravos, Tejuco, 1752. b) APM, CC 2.048, n. 247, fl. 124, Matrícula de escravos, Tejuco, 1752.

A correlação entre o significado de geja como nação e seu significado como marca ritual foi também identificada por Silva Júnior para a Bahia em um inventário post-mortem de 1720 acerca dos bens do mestre de campo Ventura Ferreira Vivas, residente em Salvador. O notário descreve 
que havia em sua propriedade um "molecão novo do gentio da Mina com três geges em cada uma das faces". ${ }^{34}$

Esta evidência confirma que tanto a grafia da região diamantina (geja) quanto a grafia baiana (gege) são variações de um mesmo termo que atestam um importante nexo entre origem ("nação geja”/“nação gege”) e marcas rituais (“com gejas", "três geges em cada uma das faces”). As gejas encontradas em Minas seriam então escarificações específicas que adornavam os africanos de origem gbe? Seria o nome das marcas que permitiam identificar a nação jeje/geja? O nome das marcas deu origem ao nome da nação? Ou o nome da nação deu origem ao nome das marcas? Por que no Tejuco a palavra geja era extensamente utilizada para designar marcas rituais e não para a nação?

Para desenvolver as questões que norteiam este trabalho, elaboramos três hipóteses explicativas principais: a primeira privilegia dimensões linguísticas ao considerar o impacto dos idiomas gbe na formação do campo semântico das modificações corporais intituladas gejas; a segunda hipótese a ser testada sublinha as características dos padrões dos desenhos formados pelas gejas e sua adoção como parâmetro para a nomeação e descrição de cicatrizes em qualquer grupo; a terceira hipótese aborda a distribuição das marcas gejas por nações com o objetivo de verificar sua especificidade em relação às origens adjas. Todas estas possibilidades analíticas convergem para um eixo central que é a predominância da população falante de línguas gbe no distrito diamantino. É em torno desta dimensão que o argumento do artigo será construído.

34 Arquivo Público do Estado da Bahia (APEB), Salvador, Seção Judiciário (SJ), 03/1416/1885/02, Inventário post-mortem de Ventura Ferreira Vivas, Salvador, 1720 (grifo nosso), apud Silva Júnior, “Ardras, minas e jejes”, p. 9. Este é o único registro que temos do uso do termo para escarificações no contexto baiano, o que não significa que não fosse corrente também naquele cotidiano, visto que Minas era parte do mesmo complexo gbe no qual a Bahia estava integrada. A diferença pode ser que, em Minas, a descrição das marcas e o registro dos marcadores de origens africanas estava no centro das políticas de controle social da administração colonial, por isso temos documentação disponível. 


\section{Em busca de evidências etimológicas: atinjijá [àtí dz̄i dzá] e jija [dz̄i dzá]}

A grande concentração de grupos étnicos falantes de línguas gbe na área mineradora do interior do Brasil resultou na emergência de um conjunto de práticas comunicativas que os portugueses chamaram de língua geral da mina. Historiadores e linguistas argumentam que ela se constituiu a partir dos variados graus de intercomunicabilidade que já existiam na África entre os idiomas falados nas principais regiões da Costa da Mina. Isto não significa a ausência de barreiras linguísticas entre eles, como Hounnouvi chamou atenção recentemente. ${ }^{35}$ A base lexicográfica da língua mina, argumentam Castro e Yai, teria sido o fongbe do reino do Daomé. Além das línguas gbe, parte de seu léxico conteria também uma pequena influência iorubá, em razão da presença dos nagôs na capitania mineradora, que ali poderiam ser classificados dentro do guarda-chuva mina (nação nagô ou mina nagô). ${ }^{36}$ Como apontado no Quadro 1, grupos mahi (nação sabarú, maquino/maquiné e cobu) também foram trazidos para a região, então é muito provável que eles igualmente imprimissem influência mahi no uso dinâmico da então denominada língua mina. ${ }^{37}$

O mais importante registro escrito da língua mina foi realizado por Antônio da Costa Peixoto na região de Ouro Preto durante as décadas de 1720 e 1730, tendo sido posteriormente enviado para Portugal com

35 Hounnouvi levanta importantes questões quanto aos limites desta intercomunicabilidade. Cf. Christian Hounnouvi, "Povos Gbe da Costa da Mina: questionando a intercompreensão e a identidade linguística” in Ivana Stolze Lima, Juliana Farias e Aldair Rodrigues (orgs.), A diáspora Mina: africanos entre o Golfo do Benim e o Brasil (Rio de Janeiro: Nau, 2020), pp. 51-80.

36 Castro, A língua mina-jeje no Brasil; Olabiyi Yai, "Texts of Enslavement: Fon and Yoruba Vocabularies from Eighteenth-and Ninetheenth-century Brazil” in Paul Lovejoy (org.), Identity in the Shadow of Slavery (London: Continuum, 2000), pp. 102-112.

37 Sobre o tráfico de mahis no século XVIII, consultar: Mariza Soares, Diálogos Makii de Francisco Alves de Souza: manuscrito de uma congregação católica de africanos Mina, 1786, São Paulo: Chão Editora, 2019; Mariza Soares, Devotos da cor: identidade étnica, religiosidade e escravidão no Rio de Janeiro, Século XVIII, Rio de Janeiro: Civilização Brasileira, 2000. 
esperança de publicação. Segundo Lima, o processo de registro do vocabulário envolveu uma rede de relações sociais que incluía as informantes africanas com quem o autor se relacionava no cotidiano urbano, ou seja, elas seriam, de alguma forma, coautoras do documento. ${ }^{38}$

Tais ponderações nos levam a considerar a influência linguística gbe no cotidiano da sociedade mineradora como fator que contribuiu para explicar a ampla difusão do termo geja na documentação. O vocabulário da língua geral não fornece qualquer pista sobre seu significado porque não abrange palavras do campo semântico das modificações corporais, cortes, tatuagens ou cicatrizes. Porém, lembrando que o fongbe teria fornecido importante base lexical para a língua geral, buscamos nos dicionários da língua fon, falada no Benim contemporâneo, indícios que nos permitem especular sobre a possível etimologia africana do termo geja no conjunto das marcas corporais. Para os propósitos deste estudo, utilizamos principalmente dois dicionários: o Dictionnaire Français-Fon, organizado por Höftmann e Ahohounkpanzon, de $2003,{ }^{39}$ e o dicionário on-line Fon-Français produzido no âmbito do projeto BéninLangues. ${ }^{40}$ Suas definições se complementam, mas, no caso das escarificações, comparativamente, o segundo é mais completo e fornece nuances importantes para a análise em tela, embora ele não disponibilizasse transcrições fonéticas até o momento em que esta pesquisa foi realizada. Além da consulta aos dicionários, a aproximação do variado léxico referente às modificações corporais foi complementada por meio de dados obtidos em trabalho de campo realizado no Benim em dezembro de 2019.41

38 Ivana Stolze Lima, “A voz e a cruz de Rita: africanas e comunicação na ordem escravista”, Revista Brasileira de História, v. 38, n. 79 (2018), pp. 41-63.

39 Hildegard Höftmann e Michel Ahohounkpanzon, Dictionnaire fon-français : avec une esquisse grammaticale, Köln: Rüdiger Köppe Verlag, 2003.

40 “Traductions Fongbe”, BéninLangues $\boldsymbol{\tau}$.

41 Fizemos buscas também no vocabulário organizado por Delafosse, mas os resultados se mostraram frustrantes por não cobrirem as modificações corporais. Maurice Delafosse, Manuel dahoméen : grammaire, chrestomathie, dictionnaire français-dahoméen et dahoméen-français, Paris: E. Leroux, 1894. 
No dicionário do projeto BéninLangues, a expressão genérica para definir escarificação em fon é $h w \bar{\varepsilon}$ - kisí; enquanto o ato de realizar escarificação é gbò hwè-jă atín. ${ }^{42} \mathrm{Em}$ termos conceituais, não há uma diferenciação nítida entre escarificação e tatuagem. Situam-se numa espessa zona de sobreposição: o ato de "fazer uma escarificação" e o de "fazer uma tatuagem" são ambos descritos como gbò kisí. Uma sutil diferença entre os dois vocábulos aparece no substantivo: o termo para escarificação, como vimos, é $h w \grave{\varepsilon}$ - kisí; ao passo que tatuagem pode ser hwغ̀ - hwegbigbo - hwegbugbo - kisí. Além disso, a palavra para escarificador e tatuador é a mesma: Hwegbotว. ${ }^{43}$ Já o Dictionnaire Français-Fon define tanto o ato de fazer tatuagem (tatouer) como o de fazer escarificação como gbo $h w \varepsilon .{ }^{44}$ Muitas vezes a tatuagem era obtida a partir da aplicação de substâncias colorantes no processo de controle da cicatrização dos cortes empregados na feitura das marcas.

Sabemos que a taxonomia das modificações epidérmicas pode variar enormemente, conforme o gênero de quem a porta, o momento da vida em que foi realizada, os múltiplos propósitos de sua confecção, e os jogos simétricos e assimétricos que se formavam com os números de cortes somados ou multiplicados etc. Muitas vezes as formas de se referir às marcas nos contextos africanos expressam estas operações matemáticas. Infelizmente, os dicionários consultados não cobrem a complexidade dessa nomenclatura na área gbe, tal como encontramos para a área iorubá, sobre a qual há um processo de dicionarização mais completo em razão de uma antiga tradição de inventariação da terminologia das marcas corporais. No caso das escarificações que integram os ritos de iniciação ao culto dos voduns, tendencialmente a terminologia se forma por meio da adoção do nome do vodum como prefixo, acrescido de $h w \varepsilon$. Desse leque,

\footnotetext{
42 “Traductions Fongbe”.

43 "Traductions Fongbe".

44 Höftmann e Ahohounkpanzon, Dictionnaire français-fon, p. 379 e p. 395.
} 
localizamos apenas uma definição dicionarizada relativa às marcas dos filhos do vodum da varíola Sakpata: sakpatàhwe. ${ }^{45}$

Ampliando a busca dentro do campo das modificações corporais, localizamos na dicionarização de Höftmann e Ahohounkpanzon um termo foneticamente próximo das ocorrências mineiras geja ou geija: atinjija [àtí dz̄i d dzá]. ${ }^{46} \mathrm{O}$ prefixo atin isolado significa árvore/planta; no contexto das marcas designa substâncias de origem vegetal em pó ou ervas inoculadas nas cicatrizes. Jija, no jogo de duplicação de monossílabos típico das línguas gbe, funciona como o particípio do verbo jă, que quer dizer cortar/picar. Poderíamos especular então que, no léxico colonial geja, o prefixo atin teria sido abandonado e apenas as duas sílabas que formavam o particípio do ato de cortar seriam retidas. Em sua dicionarização no projeto Bénin Langue (fongbe - francês), atinjija é definida apenas como escarificação de imunização tradicional ("scarification d'immunisation traditionnelle"). ${ }^{47}$

Em pesquisa de campo realizada nos arredores de Cotonu e Porto Novo em dezembro de 2019, encontramos definições bem mais precisas para atinjija que completam as informações extraídas dos dicionários. Segundo Cristoph Agbonu, Atinjija seriam cicatrizes pequenas feitas para proteção contra doenças e forças disruptivas do mundo invisível. Tais incisões guardam uma série de particularidades estéticas em relação ao conjunto mais amplo das marcas rituais. Quanto à extensão, caracterizam-se por serem necessariamente pequenas; quanto à localização, podem estar no rosto ou em qualquer parte do corpo, conforme os propósitos subjacentes a sua feitura. Uma melhor definição de suas particularidades pode ser obtida quando contrastadas, por exemplo, com as marcas que indicavam pertencimento às coletividades familiares. Enquanto estas eram uma obrigação e se localizavam normalmente na face, as marcas classificadas como atinjija eram realizadas tendencialmente por iniciativa

\footnotetext{
45 "Traductions Fongbe".

46 Höftmann e Ahohounkpanzon, Dictionnaire fon-français.

47 "Traductions Fongbe".
} 
de adolescentes ou adultos e poderiam ser inscritas em qualquer parte do corpo. Evidentemente, uma não exclui a outra. Uma pessoa poderia trazer as marcas de sua linhagem e as pequenas incisões atinjija pelo rosto ou pelo corpo. ${ }^{48}$

Se geja derivasse de atinjija, seu significado teria sido ampliado e transformado no cotidiano colonial porque as descrições das incisões a partir do termo geja, em alguns casos, indicam que não seriam necessariamente pequenas. Foram qualificadas pelos oficiais da intendência ora como grandes (“gejas grandes”); ora como pequenas, mais próximas da hipótese de serem atinjija. Por exemplo, Manoel Ladá, tinha "uma geja pequena em cada uma das faces e o mais tudo liso e no peito com uma geja”. ${ }^{49}$ Antônio Nagô trazia "uma geja grande como chapa na fonte direita e a fonte esquerda toda picada da orelha até o canto do olho, com três riscos em cada uma das faces e um sinal sobre a sobrancelha direita". ${ }^{50}$ A maioria das gejas não tem sua extensão caracterizada, mas os detalhes de sua localização nas partes do rosto indicam que seriam provavelmente formadas por pequenos cortes ou pontilhados. Nesta linha especulativa, haveria uma generalização do termo utilizado para designar marcas rituais.

Se enfatizarmos agora o particípio jija [dz̄ì dzá] do verbo cortar, jă [dzá], que guarda grande semelhança com geja, a pronúncia do j fricativo na segunda sílaba se mostra muito parecida com sua transcrição em português, talvez fosse esse o modo como o escrivão a ouvia. Como vimos, o ato de fazer escarificação é gbò hwè - jă atín, ${ }^{51}$ e, de forma isolada, o termo jija [dz̄̄ dzá] é o particípio do verbo jă (cortar, romper, picar). ${ }^{52}$

Neste exercício especulativo, teria havido pouca transformação fonética entre jija e geja. Se esta hipótese for plausível, a palavra geja teria surgido de um particípio do fongbe, ou também de outras línguas

48 Comunicação pessoal com Cristoph Agbonu, em 13 de dezembro de 2019, em Cotonu.

49 APM, CC 2.048, n. 39, fl. 20, Matrícula de escravos, Tejuco, 1752.

50 APM, CC 2.048, n. 60, fl. 30v, Matrícula de escravos, Tejuco, 1752.

51 “Traductions Fongbe” (grifo nosso).

52 “Jijá, I. adj - découpé; II. acte m (fait m) de découper”, Höftmann e Ahohounkpanzon, Dictionnaire fon-français, p. 243. 
gbe, e sido incorporada ao português como um termo sinônimo de corte, transformando-se em substantivo. Seu sentido seria então genérico, diferentemente da hipótese derivada de atinjija, cicatrizes pequenas, e não designaria nenhum dos termos que compunham a complexa nomenclatura africana das marcas corporais.

Em síntese, a nação geja poderia ser aquela dos grupos cuja incidência de escarificações era sublinhada com uma palavra de origem gbe significando que eram pessoas que portavam marcas pequenas denominadas atinjija (atinjija > geja), ou a palavra geja poderia simplesmente designar "pessoas marcadas com cortes rituais" ou "pessoas cortadas" (jija do particípio de jă significando cortar > geja). Neste último caso, o léxico do campo semântico das escarificações teria influenciado a constituição da nomenclatura de origem dos povos, a nação, que usavam aquelas palavras para falar genericamente de escarificações: nação geja (ou gege). Originalmente não tinham um sentido étnico, mas assim passaram a ser retidas e conotadas nos meandros da classificação das origens na diáspora. Partindo do fato de que geja era uma nação no circuito do tráfico ligado à Costa da Mina, no registro colonial ela teria se formado a partir da etnicização das formas como as marcas eram descritas nas línguas gbe. A origem da nomenclatura da nação poderia ser derivada então de duas possibilidades relativas ao campo semântico das escarificações: atinjija (tipo específico) ou jija (termo genérico).

O conjunto de evidências etimológicas aqui mobilizado, por mais que pareça animador, deve ser observado com cautela. A especulação interpretativa com base em dicionários contemporâneos para analisar um fenômeno do século XVIII nos parece bastante arriscada para ser tomada de forma linear e definitiva. Primeiro, porque o fongbe não tinha abrangência ou estatuto de língua nacional e o reino do Daomé, onde principalmente se falava essa língua, estava ainda em processo de afirmação da sua hegemonia na região, que se tornou posteriormente a República Popular do Benim. Segundo, porque os desenhos das escarificações e seus significados são históricos, portanto nunca foram estáticos. Poderiam passar 
por transformações em razão de deslocamentos populacionais, interações étnicas e dinâmicas sociais e políticas. Ademais, parte dos ornamentos poderia ser alterada de uma geração para outra, sobretudo em razão das margens de escolha nas marcas que não eram feitas por obrigação ou preceito. Junto com estas transformações, a nomenclatura também poderia variar historicamente. Por isso, para avançar na análise dos significados de geja em bases mais sólidas, acreditamos ser prudente confrontar essas possibilidades de interpretação etimológica com evidências produzidas no contexto de descrição das escarificações em que as gejas aparecem. Iremos considerar as características das marcas no seu detalhamento pelo olhar colonial e sua distribuição proporcional em relação às nações. Em poucas palavras, passaremos a cartografar os vestígios corporais que possam elucidar as nuances e complexidades de seus sentidos no interior da América portuguesa do século XVIII.

\section{As características das gejas}

Em termos globais, as gejas foram vinculadas a incisões epidérmicas localizadas sobretudo nas fontes ${ }^{53}$ (47 menções) e, em menor frequência, nas faces ${ }^{54}$ (26 menções), peitos (19 menções) e na região das sobrancelhas (18 menções), principalmente no meio delas. Poucas vezes localizam-se na barriga, braços e nuca.

53 Segundo o Vocabulário de Bluteau, fonte é a "parte da cabeça nas extremidades da testa, entre os olhos e as orelhas”, Raphael Bluteau, Vocabulario portuguez e latino, aulico, anatomico, architectonico, bellico, botanico, brasilico, comico, critico, chimico, dogmatico, dialectico, dendrologico, ecclesiastico, etymologico, economico, florifero, forense, fructifero, Coimbra: Collegio das Artes da Companhia de Jesus, 1727, v. 4, p. 164.

54 Na concepção de quem fez os registros das marcas, as faces seriam a região do rosto abaixo dos olhos. Ela está coerente com a definição do Vocabulario de Bluteau sobre face: "aquela parte do rosto, que de uma e outra parte, debaixo da testa e dos olhos, se estende até à barba”, Bluteau, Vocabulario portuguez, v. 4, p. 7. 
Nem sempre as gejas tiveram suas características esmiuçadas, mas, com base nas vezes em que isto aconteceu, chamam atenção aquelas que formavam pequenos cortes ou pontos, tanto em baixo-relevo (entrantes) como queloidais (salientes, em alto-relevo). Tais sinais são enfatizados em contraste com cortes traçados por meio de riscos lineares mais extensos. Por exemplo, João de nação sabarú, de 25 anos, apresentava "riscado nas fontes e três gejas pequenas em cada canto dos olhos". ${ }^{55}$ Esse contraste entre gejas formando pequenos pontilhados e os riscos longitudinais ganha mais plausibilidade quando observamos a descrição das marcas de Manoel, 22 anos, também de nação sabarú, que tinha “dois riscos em cada uma das fontes, pegando da orelha até o canto do olho, duas gejas como bexigas grandes na face direita e os mais todos sinais de Sabarú". ${ }^{56}$ Ou seja, as duas gejas lembravam cicatrizes de varíola, "bexigas”, que se formavam a partir das lesões cutâneas resultantes das bolhas purulentas que caracterizavam aquela doença.

Além dos sabarus, outros grupos também tinham marcas corporais próximas dessas configurações pontilhadas que parecem contrastar com os riscos mais longos. Francisco de nação ladá, trinta anos, era "fula da cara com duas gejas entre as sobrancelhas e duas em cada uma das faces, gejas nas fontes e a cara riscada”. ${ }^{57}$ Seu rosto era adornado com gejas, possivelmente pequenas incisões, dispostas em um par entre as sobrancelhas e um par em cada face, além de outras nas fontes cujo número não foi especificado. Nesses casos elas seriam diferentes dos riscos na face, “cara riscada”. Já o escravizado João, de nação ouemé, de dezoito anos, era "picado de bexigas com gejas em ambas as fontes, dois riscos pequenos na testa, e com nove riscos em cada um dos braços, avaliado em 300\$000”. ${ }^{58} \mathrm{O}$ escrivão distingue então suas cicatrizes de

55 APM, CC 2.048, n. 331, fl. 166, Matrícula de escravos, Tejuco, 1752.

56 APM, CC 2.048, n. 57, fl. 29, Matrícula de escravos, Tejuco, 1752 (grifo nosso).

57 APM, CC 2.048, n. 88, fl. 44v, Matrícula de escravos, Tejuco, 1752.

58 APM, CC 2.048, n. 4, Matrícula de escravos, Tejuco, 1752. 
varíola das suas marcas gejas e das escarificações formadas por riscos na testa e nos braços.

Outro elemento que poderia oferecer uma pista interessante acerca da hipotética especificidade das gejas em relação às demais escarificações é seu efeito visual queloidal em geral, não apenas no caso dos pontilhados. Antonio Mina, 35 anos, era "liso da cara e com a barriga cheia de gejas grandes de altura do dedo avaliado em 280.000”. ${ }^{59}$ Essas marcas poderiam servir de instrumento para a recuperação de Antônio após a matrícula, pois ele conseguiu escapar do cativeiro em 2 de janeiro de 1753, conforme informação à margem de sua ficha. A matrícula de João Cobu informava que ele tinha a "cara redonda e lisa, picado de bexigas, testa curta, e uma geja grande levantada no meio do peito”. ${ }^{60}$ Já Antônio, de nação fon, de 28 anos, apresentava "as faces ambas picadas e uma cicatriz pequena no pescoço da parte esquerda e duas gejas grandes levantadas no peito". ${ }^{61}$ Esta hipótese sobre o efeito visual das gejas ser constituído por pontilhados e por cicatrizes em alto-relevo ganha reforço se considerarmos as evidências presentes em jornais do século XIX, sistematizadas por Jeha. Segundo a autora, "a maioria das marcas jejes nos anúncios de fuga tinham relevo. Por exemplo, a jovem Rita Gege tinha 'pela cara e corpo bastante borbulhas'; Francisco Gege tinha no rosto 'dois sinais à semelhança de lombinhos"”. ${ }^{62}$

Nos casos das "gejas levantadas" encontradas no distrito diamantino, podemos supor que na África o processo de cicatrização das incisões foi controlado para que adquirissem aspecto queloidal. O efeito visual era dimensionado em relação à expectativa da sensação tátil que poderia ser despertada quando as marcas fossem tocadas. Este tipo de

59 APM, CC 2.048, n. 155, fl. 78, cc. 2048-082, Matrícula de escravos, Tejuco, 1752 (grifo nosso).

60 APM, CC 2.048, n. 362, fl. 181v, Matrícula de escravos, Tejuco, 1752 (grifo nosso).

61 APM, CC 2.048, n. 275, fl. 138, Matrícula de escravos, Tejuco, 1752 (grifo nosso).

62 Silvana Jeha, Uma história da tatuagem no Brasil: do século XIX à década de 1970, São Paulo: Venta, 2019, p. 113. Os anúncios transcritos pela autora, a quem agradeço por ter me chamado a atenção para este aspecto, foram recolhidos em exemplares do Correio Mercantil da Bahia respectivamente referentes aos anos 1838 e 1841. 
marca poderia envolver também técnicas de pigmentação, havendo uma sobreposição entre cicatriz e tatuagem, embora esta distinção não faça tanto sentido no contexto analisado. As técnicas empregadas para obter esse tipo de visualidade em alto-relevo incluíam cortes mais fundos na pele e o uso de substâncias irritantes extraídas de ervas que estendessem o tempo de cicatrização e provocassem ali o crescimento de tecido. No Daomé do século XX, Herskovits destaca que as marcas queloidais eram realizadas sobretudo para fruição estética e portavam conotação sexual atrelada à sensibilidade tátil que provocariam. ${ }^{63}$ Os escarificadores realizavam-nas em agosto, no auge da estação chuvosa, com o objetivo de aproveitar as temperaturas mais baixas e evitar infecções. ${ }^{64}$ Em termos comparativos globais, segundo Keefer, as marcas queloidais eram mais comuns na África centro-ocidental. A autora frisa, ainda, que por vezes os queloides eram involuntários, ocorriam em razão de dificuldades inesperadas no processo de cicatrização, que acabavam resultando no crescimento excessivo de tecido não desejado nos sulcos. ${ }^{65}$

Como já referido, nem todas as gejas foram detalhadas pelos escrivães. Quando observamos o conjunto dos registros, constatamos que a crescente familiaridade dos oficiais da matrícula com as marcas levava à generalização do termo geja para cortes e modificações epidérmicas rituais de forma bastante ampla. Algumas marcas que muitas vezes poderiam ser descritas simplesmente como "sinais" passavam a ser nomeadas como “gejas”. Nesses casos genéricos, se cruzássemos essas informações com as evidências etimológicas coletadas nos dicionários fongbe, poderíamos assumir que geja seria a grafia de jija significando genericamente o particípio do verbo cortar, cortado, querendo dizer basicamente "gente marcada” ou "gente cortada”. No Brasil, o particípio teria se tornado então um substantivo para nomear cortes rituais.

63 Melville Herskovits, Dahomey, an ancient West African kingdom, Evanston: Northwestern University Press, 1967, v. 1, pp. 291-295.

64 Herskovits, Dahomey, an ancient West African kingdom, p. 295.

65 Keefer, “Scarification and identity”, p. 540. 
Há, no entanto, uma objeção a esta forma de pensar a evidência etimológica. Trata-se do fato, já mencionado, de geja ser também um descritor de origem, nação, muito abrangente no corredor gbe ao qual Minas Gerais estava integrada. Portanto, seu sentido foi construído de forma atrelada aos meandros da classificação colonial das origens africanas, ponto que deve ser aprofundado para avançarmos no desenvolvimento de hipóteses mais conclusivas que possam definir os contornos da semântica de geja (jeje).

\section{A predominância das gejas nas nações ladá e ouemé}

A distribuição do uso da palavra geja por nação mostra que proporcionalmente ela estava associada sobretudo a dois grupos: os ladanos (ou suas variações como nação ladá, ladana ou ladano) ${ }^{66}$ e os ouemenos (em suas variações como nação ohemé ou vemé). ${ }^{67}$ Os dados são muito contundentes: dos 34 matriculados da nação ladá, 80\% (27) tiveram parte dos desenhos de suas escarificações descritos como gejas. Apenas aqueles de nação ouemé apresentaram também um percentual expressivo, embora bem atrás da nação ladá: 11 ouemenos (61\%) com marcas gejas em um total de 18 pessoas do grupo (Quadro 1). Esta prevalência contrasta com

66 Apesar de registrar as variações, neste artigo iremos estabilizar a nomenclatura para as formas ladano(s) e ladana(s) por ser aquela mais próxima ao uso corrente em Minas Gerais no século XVIII.

67 A princípio cogitamos a possibilidade de Ohemé e Vemé referirem-se a Daomé, mas a documentação produzida na Costa da Mina na década de 1750 grafa o nome do reino daomeano como "da Omet", "Daomé” ou "Dagomé". Por exemplo, num registro contábil de 1752, vemos o lançamento do pagamento de costumes ao "Rei da Omet" em Ajudá. AHU, São Tomé, cx. 9, doc. 944, Conta da carregação, Costa da Mina, 1752. Este documento foi analisado em Almeida, "Rotas Atlânticas". Além disso, na documentação mineira, o principal grupo étnico do reino do Daomé é classificado como nação fon, fono, fam, ou, raramente, dagomé (Quadro 1), sendo também como aparece no Rio de Janeiro na segunda metade da centúria, conforme os trabalhos de Mariza Soares: Mariza de Carvalho Soares, “Mina, Angola e Guiné: nomes d’África no Rio de Janeiro Setecentista”, Tempo, n. 3 (1998), pp. 73-93; Soares, Devotos da cor, p. 201. 
a baixa incidência de gejas entre os iorubás, pois emergem apenas em 8 nagôs de um total de 60! Somente em 7 de 27 couranos de Uidá; ${ }^{68}$ em 7 de 36 fons; e apenas em 5 sabarús de um grupo de 60 indivíduos da mesma origem.

Há uma relativa estabilidade na configuração dos sinais de gejas dos ladanos. Quase sempre se referem a pequenas marcas (uma, duas ou três) localizadas nas faces (23 menções), nas fontes (19 menções) e entre as sobrancelhas (11 menções) (Quadro 2). As demais dividem-se entre peito, testa e sobrancelhas. A matrícula de número onze deixa escapar uma pista que aponta a possibilidade de as gejas inicialmente se referirem a dois sinais em cada fonte. João, de "nação ohemé”, era o primeiro titular desta ficha, mas, com seu falecimento em 6 de julho de 1753, "se matriculou Paulo ladá com sinais de sua nação duas geijas em cada fonte, idade 25 anos, avaliado em 230.000”. ${ }^{69}$ Ou seja, os oficiais da intendência parecem acreditar que as marcas da nação ladá seriam “duas geijas em cada fonte”.

Quadro 2

Marcas da nação ladá

\begin{tabular}{l|l}
\hline Nome & \multicolumn{1}{c}{ Descrição das marcas } \\
\hline André & $\begin{array}{l}\text { "com um círculo picado que atravessa toda a testa, uma geja no meio } \\
\text { das sobrancelhas e uma em cada uma das faces, a cara picada e três } \\
\text { gejas no meio do peito” }\end{array}$ \\
\hline Angelo & $\begin{array}{l}\text { "com gejas em ambas as fontes, duas entre as sobrancelhas e duas em } \\
\text { cada uma das faces, uma geja grande no meio do peito, outra por baixo } \\
\text { de cada um dos peitos e outras na barriga” }\end{array}$ \\
\hline Antonio & "uma grelha de três riscos no cimo do braço esquerdo"
\end{tabular}

68 O entendimento de que os couranos são provenientes do reino de Uidá é baseado em: Moacir Maia, "De reino traficante a povo traficado: a diáspora dos courás do Golfo do Benim para as minas de ouro da América Portuguesa (1715-1760)”, Tese (Doutorado em História), Universidade Federal do Rio de Janeiro, 2013

69 APM, CC 2.048, n. 11, fl. 6, Matrícula de escravos, Tejuco, 1752. João Veme, 26 anos, tinha "três cicatrizes pequenas em cada uma das fontes, nariz chato e um sinal de bexiga no canto da boca da parte direita". 
Quadro 2 - continuação

\begin{tabular}{|c|c|}
\hline Nome & Descrição das marcas \\
\hline Antonio & $\begin{array}{l}\text { “duas gejas em cada uma das faces e uma cicatriz na cabeça por cima } \\
\text { da testa sem cabelo" }\end{array}$ \\
\hline Antonio & $\begin{array}{l}\text { "gejas em ambas as fontes, duas no cimo do nariz entre as sobrancelhas } \\
\text { e uma grande em cada uma das faces" }\end{array}$ \\
\hline Antonio & $\begin{array}{l}\text { "com gejas em ambas as fontes, duas pequenas em cada uma das faces } \\
\text { e duas pequenas levantadas na testa” }\end{array}$ \\
\hline $\begin{array}{l}\text { Antonio } \\
\text { Farçola }\end{array}$ & $\begin{array}{l}\text { “com três gejas pequenas em cada uma das faces e toda a mais cara lisa } \\
\text { com várias gejas pequenas em todo o peito” }\end{array}$ \\
\hline Cristóvão & “com gejas em ambas as fontes picado de bexigas” \\
\hline Francisco & $\begin{array}{l}\text { “com gejas nas fontes e dois riscos pequenos ao pé da sobrancelha } \\
\text { esquerda da parte da fonte” }\end{array}$ \\
\hline Francisco & $\begin{array}{l}\text { “com duas gejas em cada uma das fontes, outra por cima da sobran- } \\
\text { celha esquerda e a mais cara lisa, com o peito picado” }\end{array}$ \\
\hline Francisco & $\begin{array}{l}\text { "com duas gejas entre as sobrancelhas e duas em cada uma das faces, } \\
\text { gejas nas fontes e a cara riscada” }\end{array}$ \\
\hline Francisco & $\begin{array}{l}\text { "com uma geja em cada uma das faces e outra no cimo do nariz e uma } \\
\text { cicatriz no canto da sobrancelha esquerda” }\end{array}$ \\
\hline Francisco & $\begin{array}{l}\text { “com duas gejas em cada uma das faces e na esquerda uma cicatriz } \\
\text { pequena por baixo do olho” }\end{array}$ \\
\hline $\begin{array}{l}\text { Francisco } \\
\text { Barbeiro }\end{array}$ & $\begin{array}{l}\text { “com duas gejas pequenas em cada uma das faces e } \\
\text { quatro em cada fonte” }\end{array}$ \\
\hline Gonçalo & $\begin{array}{l}\text { "liso e fula da cara com gejas em ambas as fontes, duas nas faces e } \\
\text { duas entre as sobrancelhas" }\end{array}$ \\
\hline João & $\begin{array}{l}\text { “com gejas em cada uma das fontes, uma geja em cima de cada uma } \\
\text { das sobrancelhas, outra geja em cada uma das faces” }\end{array}$ \\
\hline João & $\begin{array}{l}\text { "cara lisa, dois sinais como de bexiga na fonte direita e quatro na fonte } \\
\text { esquerda" }\end{array}$ \\
\hline João & "riscado nas fontes e duas gejas pequenas em cada uma das faces” \\
\hline João & $\begin{array}{l}\text { “com gejas em ambas as fontes e uma em ambas as faces com toda a } \\
\text { mais cara lisa” }\end{array}$ \\
\hline
\end{tabular}


Quadro 2 - continuação

\begin{tabular}{|c|c|}
\hline Nome & Descrição das marcas \\
\hline João Alferes & $\begin{array}{l}\text { "fula da cara e toda ela lisa, uma cicatriz de porrete na cabeça por cima } \\
\text { da orelha direita, com o peito todo picado" }\end{array}$ \\
\hline Joaquim & $\begin{array}{l}\text { "com uma cicatriz grande de porrete em cima da sobrancelha esquerda } \\
\text { com gejas em ambas as fontes e uma em cada face e duas gejas no } \\
\text { cimo do nariz” }\end{array}$ \\
\hline José & $\begin{array}{l}\text { “com dois riscos pequenos em cada uma das faces e um sinal redondo } \\
\text { na barba da parte direita” }\end{array}$ \\
\hline José & $\begin{array}{l}\text { "com gejas em ambas as fontes e uma grande em cada uma das faces e } \\
\text { outra na frente da testa” }\end{array}$ \\
\hline José & $\begin{array}{l}\text { “com cara e testa lavrada com uma geja em cada uma das faces e duas } \\
\text { entre as sobrancelhas” }\end{array}$ \\
\hline José & $\begin{array}{l}\text { "com gejas em ambas as fontes, duas grandes em cada face e duas mais } \\
\text { pequenas entre as sobrancelhas” }\end{array}$ \\
\hline Manoel & $\begin{array}{l}\text { “com uma geja pequena em cada uma das faces e o mais tudo liso e no } \\
\text { peito com uma geja” }\end{array}$ \\
\hline Manoel & $\begin{array}{l}\text { "com duas gejas em cada uma das faces e duas entre as sobrancelhas e } \\
\text { gejas nas fontes” }\end{array}$ \\
\hline Mateus & $\begin{array}{l}\text { “com gejas em ambas as fontes, e uma em cada uma das faces, com } \\
\text { uma [velida] no olho direito” }\end{array}$ \\
\hline Miguel & $\begin{array}{l}\text { “com uma geja grande em cada uma das faces e outra na testa e duas } \\
\text { pequenas em cada uma das fontes” }\end{array}$ \\
\hline Miguel & $\begin{array}{l}\text { “com uma geja grande em cada uma das fontes e um sinal grande e } \\
\text { redondo no queixo direito” }\end{array}$ \\
\hline Paulo & $\begin{array}{l}\text { “com gejas em ambas as fontes, uma em cada face e duas entre as } \\
\text { sobrancelhas” }\end{array}$ \\
\hline
\end{tabular}

Fonte: APM, CC 2.048, Matrícula de escravos, Tejuco, 1752.

Mesmo descendo a esse nível de análise, não é possível afirmar de modo conclusivo se as marcas gejas originalmente seriam um par de incisões localizadas nas fontes ou o nome do jogo formado pelo par quando combinado com os cortes situados no meio da testa, entre as sobrancelhas, 
e com os cortes na face, entendida como região abaixo dos olhos. Se fôssemos nos basear apenas no número de vezes em que a configuração visual mais se repetiu, a dimensão específica das marcas caracterizadas como gejas estaria localizada nas fontes (têmporas). Geja seria o nome desse padrão de visualidade? Ou seria uma leitura etnicizante (origem ou “nação”) dos grupos que comumente portavam esse padrão?

O reino de Aladá, na segunda metade do século XVII, habitado principalmente pelos aïzos, era a potência hegemônica na região do Golfo do Benim que ficou conhecida como Costa da Mina. ${ }^{70}$ Essa posição entrou em decadência com a destruição de seu principal porto, Offra, em 1692, e no início do século seguinte com a eclosão de uma série de revoltas nos reinos litorâneos que eram seus tributários. Uidá (Xwéda), com capital em Savi, por exemplo, promoveu várias rebeliões até conseguir sair do jugo de Aladá. Nesse contexto, no ano de 1721, foi fundada em seu território a feitoria portuguesa de Ajudá. O golpe mortal no poderio de Aladá foi a invasão do seu reino em 1724 pelas tropas do rei do Daomé. ${ }^{71}$ Do mesmo modo, o reino Uidá caiu em 1727, mas o porto de Ajudá, agora sob controle daomeano, continuava sendo extremamente importante para o tráfico. A partir da década de 1740, como reação às pressões monopolistas da elite do Daomé no fornecimento de pessoas para o tráfico, os comerciantes de origem europeia foram se deslocando para pontos situados mais ao leste, principalmente Porto Novo. ${ }^{72}$

A antiga hegemonia de Aladá no tráfico atlântico se refletia na ampla difusão do termo ardra (e suas variações arada, arara, ardre, arde etc.) na classificação dos africanos da Costa dos Escravos presentes em várias sociedades escravistas das Américas. ${ }^{73}$ Parés, com base em

70 Segundo Law, os aizo eram grupos autóctones que habitavam a região de Aladá no momento da chegada dos adjas que vieram de Adja-Tado, onde hoje situa-se o Togo. Cf. Law, The kingdom of Allada, p. 35.

71 Law, The kingdom of Allada; Isaac Akinjogbin, Dahomey and its neighbours, pp. 1-68.

72 Silva Júnior, “Interações atlânticas entre Salvador e Porto Novo”.

73 No diário de Reynaud Des Marchais, cartógrafo e navegador francês familiarizado com a Costa da Mina, datado da primeira metade da década de 1720, lemos que os 
Reynaud Des Marchais, explica que ardra era uma nomenclatura de nação abrangente e empregada para nomear as origens de pessoas deportadas da região comercial controlada pelo reino de Aladá, normalmente oriundas de zonas adjacentes e não seus próprios súditos. ${ }^{74}$ Já no contexto da conquista de Aladá pelo Daomé em 1724, os ladanos passaram a ser alvos da escravização, sendo vendidos principalmente no porto de Ajudá.

As fontes brasileiras do século XVIII refletem essas transformações. Na Bahia, os trabalhos de Soares, Parés e Silva Júnior apontam uma diminuição do termo ardra nas primeiras décadas do Setecentos e, inversamente, a emergência do termo Mina e, progressivamente, gege na classificação da população falante de línguas gbe, sobretudo na década de $1740 .^{75}$ Tal inflexão afro-atlântica é visível também nas fontes cartoriais e fiscais de Minas Gerais. A presença de falantes de aladagbe na zona da mineração fez com que a conceitualização de sua origem ocorresse por meio das variações ladá, ladano, ladana, grafadas em português de modo mais permeável à forma como narravam o lugar de onde vinham: Alladahonu. ${ }^{76} \mathrm{O}$ sufixo "nu” originalmente significa "da terra de"; no caso, da terra de Aladá. Além disso, na sua incorporação ao português o termo passou a variar em gênero (ladano/ladana). Ou seja, a nomenclatura que designava a classificação dos africanos por origem não é estática, mas está atrelada a dinâmicas africanas, configurações geopolíticas do tráfico e experiências dos escravizados na diáspora.

ardras "homens, mulheres e crianças de peito são marcados com pequenas incisões nas bochechas. Aqueles que são escravos dos grandes de seus países, têm cortes na testa” (p. 125). Portanto, as marcas ladanas, mais incidentes nas têmporas, destoam deste diagnóstico. Jean-Baptiste Labat, Voyage du chevalier Des Marchais en Guinée, isles voisines, et a Cayénne fait en 1725, 1726 et 1727. Paris: Saugrain l'aîné, 1730.

74 Parés, A formação do candomblé, pp. 44-45.

75 Silva Júnior, “Ardras Minas e Jejes”, pp. 24-25; Carlos Eugênio Líbano Soares e Carlos da Silva Júnior, “Uma nova guiné’: africanos em inventários e registros de batismo na cidade da Bahia da primeira metade do século XVIII”, História Unisinos, v. 14, n. 3 (2010), pp. 243-257; Parés, A formação do candomblé, p. 68.

76 Anatole Coissy, “L'arrivée des 'Alladahonou' à Houawe'”, Études dahoméennes, n. 13 (1955), pp. 33-34. 
A presença ladana em Minas pode ter levado aquela sociedade a instrumentalizar as formas de se referir aos padrões mais frequentes das marcas desse grupo como balizas para classificar as marcas de outros povos. Assim, o significado de geja oscilava descontinuamente entre a designação de algo específico identificado nas escarificações ladanas e a tendência a servir de parâmetro e referência para a nomeação de desenhos de outros povos. Além da maior associação de gejas ao grupo ladá (27 dos 34 matriculados da nação ladá, tiveram detalhes de suas escarificações descritos como gejas), tal hipótese poderia ser sustentada pelos casos em que pessoas de outras nações eram descritas com "sinais de ladá”. Embora não especifiquem os desenhos, supondo que os interlocutores entenderiam o significado da locução, ocorrências como esta são identificadas em oito matrículas, todas elas envolvendo nagôs (cinco pessoas) e baribas (três pessoas). Na matrícula 89, após o falecimento de Manoel Cobu em 1756, entrou em seu lugar "Thomé Nagô picado de bexigas com sinais de ladá", “de 20 anos, avaliado em 220 mil reis”. ${ }^{77}$ Já no lugar de João Cobu, na ficha 181, "se matriculou Gaspar Nagô, sinais de ladá, idade 22 anos, avaliado em 240 mil réis".$^{78}$ Na matrícula 73, o escrivão da intendência inscreveu Romão Barbá, "picado de bexigas com sinais de ladá”, "idade de 25 anos”, avaliado em 190 mil réis, no lugar de Bartolomeu Angola, após seu falecimento em 1754. ${ }^{79}$ Manoel Sabarú, morto em 1758, foi substituído por "Theodosio Barba, com sinais de ladá, idade 30 anos, avaliado em 230\$000". ${ }^{80}$ Esse fenômeno ocorria também em outras partes da capitania mineradora. Por exemplo, em Mariana, encontramos “Escolástica de nação nagô com sinais de ladana” no testamento de Antônio Pereira Machado, de $1760 .{ }^{81}$

77 APM, CC 2.048, n. 89, fl. 45, Matrícula de escravos, Tejuco, 1752.

78 APM, CC 2.048, n. 181, fl. 91, Matrícula de escravos, Tejuco, 1752.

79 APM, CC 2.048, n. 73, fl. 37, Matrícula de escravos, Tejuco, 1752.

80 APM, CC 2.048, n. 134, Matrícula de escravos, Tejuco, 1752.

81 Arquivo Histórico da Casa Setecentista de Mariana (AHCSM), Registros de Testamentos, liv. 53, fl. 106, Testamento de Antônio Pereira Machado, Mariana, 1760. 
Seria possível concluir então que havia uma interpretação colonial baseada no cruzamento entre origens e marcas corporais. É provável que o escrivão, em diálogo com os demais oficiais da matrícula e possíveis intérpretes africanos, atribuísse a nação privilegiando o elemento linguístico, mas encontrava padrões nas escarificações dos grupos minoritários, como baribas e nagôs, que seriam parecidas com os tipos de marcas predominantes nos grupos que mais chegavam em Minas Gerais. Buscavam um parâmetro visual naquele processo. Essas associações e analogias não levavam em conta deslocamentos populacionais, interações e trânsitos étnicos e culturais que ocorreram na África Ocidental. Law argumenta que as fronteiras entre os territórios iorubás e os territórios adjás eram muito mais porosas do que o imaginário eurocêntrico poderia esperar. ${ }^{82}$ Então não podemos descartar também a possibilidade de os grupos iorubás terem adquirido aquelas marcas em áreas adjas, antes de serem embarcados. ${ }^{83}$

Outro aspecto relacionado aos "sinais de ladá" seria a possibilidade de que os intérpretes ladinos de língua mina fossem recrutados em seu grupo entre finais da década de 1720 e inícios da década de 1730 devido à escravização em massa nos conflitos ligados à invasão daomeana de 1724.

82 Embora seja impossível determinar suas localizações geográficas de forma precisa, os nagôs trazidos para o Brasil ao longo do Setecentos seriam grupos étnicos que viviam na parte oriental dos territórios em que se falava iorubá; uma ampla região a sudoeste de Ile Ife e ao nordeste do Daomé. Consultar: Robin Law, "Ethnicity and the Slave Trade: 'Lucumi' and 'Nago' as Ethnonyms in West Africa”, History in Africa, n. 24 (1997), p. 213. David Eltis chama atenção para o fato de não haver na África, antes do século XVIII, a consciência de uma identidade pan-iorubá. Esse fenômeno tem mais a ver com as afinidades linguísticas e culturais que emergiam na diáspora. Cf. David Eltis, “A diáspora dos falantes de Iorubá, 1650-1865: dimensões e implicações”, Topoi, v. 7, n. 13 (2006), pp. 271-299; John Peel, Religious encounter and the making of the Yoruba, Bloomington: Indiana University Press, 2000.

83 Mesmo no contexto do colapso de Oió e da escravização e deportação massiva de iorubás para a Bahia, configurações como aquelas que encontramos em Minas persistiam. João Reis e Beatriz Mamigonian, analisando anúncios de escravos no século XIX, citam o caso de Luiza, de cerca de 20 anos, que era "nagô com sinais de Jeje”. Beatriz Mamigonian e João José Reis, “Nago and Mina: the Yoruba diaspora in Brazil” in Toyn Falola e Matt Childs (orgs.), The Yoruba Diaspora in the Atlantic World (Indiana: Indiana University Press, 2004), pp. 105. 
Nos registros produzidos pelos agentes da Inquisição em Minas Gerais é possível perceber a atuação de ladanos como intérpretes informais no cotidiano das relações escravistas. Por exemplo, em Mariana, no ano de 1740, Felipe Courano e Manoel Ladá, ambos ladinos, serviram de intérpretes entre Manoel Sabarú e o português João Lopes Freire. ${ }^{84}$

Como já mencionado, depois dos ladanos, o segundo grupo ao qual as marcas gejas mais foram associadas são os ouemenos - variando na documentação como “ohemé” ou “vemé” (Quadro 3) -, provavelmente oriundos do vale do rio Ouemé. Levando em conta que estamos trabalhando com registros da década de 1750, é possível que o grupo estivesse sendo enviado também via Porto Novo, que era o terminal marítimo mais próximo da região e nessa época já vinha ganhando robustez no tráfico, embora ainda fosse crescer mais em importância no decorrer da segunda metade do Setecentos. ${ }^{85}$

Quadro 3

Marcas gejas entre a nação ohemé

\begin{tabular}{c|l}
\hline \multicolumn{1}{c|}{ Nome } & \multicolumn{1}{c}{ Descrição das marcas } \\
\hline Antonio & $\begin{array}{l}\text { “com gejas nas fontes e toda a mais cara lisa, nariz grosso, com três } \\
\text { riscos por cima do embigo, três por baixo e três de cada uma das } \\
\text { partes” }\end{array}$ \\
\hline Antonio & $\begin{array}{l}\text { "com gejas pequenas em ambas as fontes, uma entre as sobrancelhas, } \\
\text { cara lisa e comprida, boca pequena” }\end{array}$ \\
\hline Caetano & $\begin{array}{l}\text { "com um círculo picado que atravessa toda a testa, duas gejas pequenas } \\
\text { em cada uma das fontes” }\end{array}$ \\
\hline Damião & $\begin{array}{l}\text { "com gejas em ambas as fontes e duas na testa, cara lisa e quatro gejas } \\
\text { no peito" }\end{array}$ \\
\hline
\end{tabular}

84 Manoel gozava de grande reputação de curador na região de Mariana e por isso foi chamado por Freire e seus irmãos para diagnosticar a causa das moléstias de seus escravos e para responder a uma série de outras questões por meio de práticas oraculares envolvendo ventriloquia. ANTT, Inquisição de Lisboa, cad. 102, liv. 295, fl. 12, Sem título, Mariana, 1740.

85 Silva Júnior, "Interações atlânticas entre Salvador e Porto Novo”. 
Quadro 3 - continuação

\begin{tabular}{l|l}
\hline Nome & \multicolumn{1}{c}{ Descrição das marcas } \\
\hline $\begin{array}{l}\text { Domingos } \\
\text { Guido }\end{array}$ & $\begin{array}{l}\text { "com gejas em ambas as fontes, uma cicatriz no meio da testa entrando } \\
\text { pelo cabelo da cabeça, e uma cicatriz no canto da boca da parte } \\
\text { esquerda” }\end{array}$ \\
\hline Feliz & $\begin{array}{l}\text { "com cara lisa e duas gejas em cada uma das fontes e uma cicatriz do } \\
\text { feitio de lua na face direita ao pé do canto da boca” }\end{array}$ \\
\hline João & $\begin{array}{l}\text { "Picado de bexigas com gejas em ambas as fontes, dois riscos } \\
\text { pequenos na testa e com nove riscos em cada um dos braços” }\end{array}$ \\
\hline Manoel & $\begin{array}{l}\text { "picado todo de bexigas com gejas nas fontes e no meio da testa duas } \\
\text { pequenas, uma cruz no peito direito e nele dois )) , e no direito tem um ( }\end{array}$ \\
\hline Matias & $\begin{array}{l}\text { "com duas gejas em cada fonte, liso da cara e uma cicatriz por baixo } \\
\text { do peito direito" }\end{array}$ \\
\hline $\begin{array}{l}\text { "filvestre } \\
\text { Guido }\end{array}$ & $\begin{array}{l}\text { "fula da cara com gejas em ambas as fontes e um sinal preto na face } \\
\text { dos braços ao pé do ombro” }\end{array}$ \\
\hline Thomé & $\begin{array}{l}\text { "Com uma geja no meio da testa, gejas nas fontes e uma cicatriz no } \\
\text { canto da boca no beiço de cima e a cara lisa” }\end{array}$ \\
\hline
\end{tabular}

Fonte: APM, CC 2.048, Matrícula de escravos, Tejuco, 1752.

Ao examinar as características das gejas ligadas à nação ouemé, constatamos que elas se assemelham às marcas ladanas em muitos pontos, pois incidem sobretudo nas fontes, no meio da testa ou entre as sobrancelhas. Por exemplo, Caetano, de trinta anos, tinha a pele adornada com "um círculo picado que atravessa toda a testa, duas gejas pequenas em cada uma das fontes”; 87 já Matias, trazia em seu rosto “duas gejas em cada fonte, liso da cara e uma cicatriz por baixo do peito direito" ${ }^{88}$ Antonio, de 22 anos, foi descrito com "gejas pequenas em ambas as fontes, uma entre as sobrancelhas, cara lisa e comprida, boca pequena”;89

86 Neste caso, o escrivão procura desenhar na ficha a marca que via no rosto de Manoel.

87 APM, CC 2.048, n. 173, fl. 87, Matrícula de escravos, Tejuco, 1752.

88 APM, CC 2.048, n. 234, fl. 117v, Matrícula de escravos, Tejuco, 1752.

89 APM, CC 2.048, n. 277, fl. 139, Matrícula de escravos, Tejuco, 1752. 
e Damião "com gejas em ambas as fontes e duas na testa, cara lisa e quatro gejas no peito". ${ }^{90}$

A elevada distribuição das marcas gejas nas pessoas classificadas como ladá e ouemé nos leva a concluir que, se o termo geja designasse algum sinal específico, ele seria constituído por cicatrizes rituais localizadas nas fontes, normalmente em pares, e entre as sobrancelhas ou no meio da testa, acompanhados de um ou dois riscos na maçã do rosto. Essa combinação, e suas variações, tendencialmente formariam um conjunto referido como marcas gejas. Inclusive não descartamos a possibilidade desta leitura estar relacionada a operações matemáticas que estabeleciam relações numéricas entre os detalhes dos desenhos. No seu processo de vulgarização, qualquer forma ou efeito visual que lembrasse as características desses sinais seria nomeado como gejas. Ou seja, a dimensão tendencialmente mais específica conviveria com sua generalização para um conjunto abrangente de cortes.

O elo entre ladanos e ouemenos que elucidaria essa tendência discrepante do maior uso de gejas para nomear suas escarificações em relação às outras nações é a origem de ambos no reino de Aladá. Na invasão daomeana de 1724, além da deportação de milhares de pessoas ladanas para as Américas, uma parcela importante foi incorporada ao domínio daomeano e um percentual relevante deslocou-se para leste, fixando-se nos arredores de Porto Novo e em suas adjacências, ao longo do rio Ouemé, resultando em novas etnogêneses, como a dos guns e dos ouemenos. ${ }^{91}$ Ambos seriam de origem adja e falantes de línguas gbe, então as marcas que traduziam visualmente as possíveis semelhanças entre esses grupos teriam sido lidas nos circuitos do tráfico como sinais de gejas. Seriam elas então marcas de povos adjas? Mesmo que originalmente não expressassem uma identidade étnica, nos deslocamentos e na formação de contrastes com outros grupos, aqueles sinais foram visualmente interpretados como marcadores de origem em conjunção com outros marcadores de diferença, tais como língua e

90 APM, CC 2.048, n. 338, fl. 169v, Matrícula de escravos, Tejuco, 1752.

91 Parés, A formação do candomblé, p. 36 e p. 53. 
práticas culturais. Esse fator estético, por não demandar interação oral num primeiro momento, pode ter aumentado a importância das escarificações na urgência que as relações comerciais do tráfico e da escravidão colocavam para a diferenciação de uma pessoa da outra.

Ao examinar evidências dos séculos XIX e XX produzidas pela administração francesa na Baía do Benim, Parés sugere duas origens etimológicas para o termo jeje. Primeiro, poderia ter derivado do topônimo Adjaché que se referia à região entre Pobé e Ketu, habitada pelos grupos adjas de etnônimo idje, que ali se refugiaram no contexto das guerras de conquista daoemanas da década de 1720. A segunda hipótese etimológica também localiza os jejes nas adjacências da região de Porto Novo (Xogbónú), onde os franceses costumavam atribuir o apelativo "djedje” aos guns de origem adja, que ali se instalaram ao fugirem das tropas do rei Agajá. ${ }^{92}$ Do lado africano, o termo aparecia circunscrito aos guns; do lado brasileiro, ao ser "apropriado e transformado pelos comerciantes baianos sob a forma jeje, passou a denominar, na Bahia, uma pluralidade de povos adjas". ${ }^{93} \mathrm{O}$ autor cita uma explicação de 1848 , por meio da qual o cônsul da França na Bahia, conde de Castelnau, trazia nuances para a historicidade dos circuitos do tráfico por onde os adjas eram trazidos para Salvador: "os jejes ou daomeanos que formam uma nação poderosa [...] antigamente embarcavam em Uidá, mas a maior parte hoje em dia vem por Porto Novo", ${ }^{94}$

Com base nessas considerações, seria razoável supor que a nação geja e as marcas gejas que encontramos em Minas Gerais no século XVIII estivessem relacionadas aos jejes deportados principalmente via Ajudá, que “antigamente embarcavam em Uidá”, como explicava Castelnau. ${ }^{95}$ Se em Porto Novo o termo ficou associado aos guns de origem adja, em

92 Parés, A formação do candomblé, pp. 51-52.

93 Parés, A formação do candomblé, p. 52.

94 Verger, Fluxo e refluxo: do tráfico de escravos entre o Golfo do Benin e a Bahia de Todos os Santos, Salvador: Corrupio, 2002, p. 15, apud Parés, A formação do candomblé, pp. 56-57.

95 Verger, Fluxo e refluxo, p. 15, apud Parés, A formação do candomblé, pp. 56-57. 
Minas ele estava associado principalmente aos ladanos e aos ouemenos, também grupos de origem adja e, em menor proporção, a uma variedade de nações, sobretudo aquelas vinculadas à territorialidade afro-ocidental que os portugueses chamavam de Costa da Mina.

Concluindo que a grafia geja era uma variação mineira da palavra jeje, seguimos no caminho aberto pela tese de Parés segundo a qual a denominação se aplicava no tráfico a algum grupo específico (no caso de sua análise, aos que estavam nos arredores de Porto Novo), sendo que houve posteriormente uma "expansão semântica do termo", com base em elementos culturais que compartilhavam, como a intercompreensão linguística e o culto aos voduns. ${ }^{96} \mathrm{~A}$ análise do vocábulo geja no contexto diamantino aponta que a associação de geja com o particular e com o geral varia conforme o contexto brasileiro e o porto de embarque. No caso mineiro, estava mais conectada ao porto de Ajudá.

De toda forma, nestes processos há uma convergência quanto a sua densa vinculação, embora não exclusiva, aos povos falantes de línguas gbe. Mesmo que o itinerário de sua formação não possa ser delineado com precisão, essa dinâmica atrelada a um complexo cultural mais amplo era o que dava inteligibilidade à ampla difusão do vocábulo geja no espaço afro-brasileiro, tanto para descrever o conjunto dos povos gbe na Bahia (gege/jeje) como para detalhar as escarificações dos afro-ocidentais na região dos diamantes (geja).

A grafia geja de Minas Gerais associada aos ladanos e ouemenos, ambos de origem adja, nos permitiria reiterar a hipótese de Verger segundo a qual a denominação jeje seria derivada do termo adja, sobretudo por conta da última sílaba ser registrada no distrito diamantino invariavelmente como "ja”. Nesta senda analítica, teria havido uma duplicação silábica, ge + ja, no processo de formação do termo geja:

96 Parés, A formação do candomblé, pp. 56-57. 


\section{ADJA > geja ou geija}

[Minas Gerais]

A partir da identificação dos padrões mais frequentes entre as escarificações inscritas na pele dos ladanos e dos oumenos, os traficantes e os escrivães, com a mediação dos africanos, teriam adotado aquela configuração como marcador visual dos grupos que perfilavam aquelas cicatrizes com maior frequência. Os gejas (ou geges e jejes na variação baiana) seriam então grupos de origem adja que traziam pequenos pontilhados em alto-relevo em seus rostos, principalmente nas fontes, na testa e entre as sobrancelhas. Em razão da frequência com que apareciam entre os falantes de idiomas gbe, elas se tornariam as marcas dos povos de origem gbe que estavam sendo classificados, e etnicizados, como geges (ou jejes) na Bahia na primeira metade do século XVIII. Em Minas Gerais aquelas cicatrizes específicas, ou algo que se assemelhasse a sua textura ou a seus efeitos visuais, seriam paulatinamente reduzidas a gejas, denotando sinais de nações geges ou gejas. Com o tempo, o significado de geja vinculado à escarificação expandiu-se de forma aleatória, abrangendo sinais que apresentassem visualidade semelhante em algum grau àquelas incisões comuns nas nações ladá e ouemé ou nos grupos gbe em geral. Em seu uso diaspórico, o vocábulo geja tenderia a oscilar entre alguma especificidade, ligada a padrões daquelas nações, e a sua generalização. Os contornos desse processo não são nítidos, de toda forma, nos interessa mais identificar as dinâmicas de seus usos diaspóricos do que traçar com exatidão sua origem na África.

\section{A tradução visual da diáspora gbe}

No circuito baiano do tráfico, em meados do século XVIII, gege ou jeje (variações da grafia mineira geja) já seria um metaetnônimo inclusivo relativamente estável aplicado aos povos falantes de línguas gbe. Como 
já referido, seu significado era definido num processo de etnogênese que emergia a partir das afinidades linguísticas, culturais e identitárias que compartilhavam. ${ }^{97}$ Porém, dada a tradição em Minas Gerais de aplicar a nação mina para a descrição abrangente principalmente dos grupos gbe e dada a necessidade de diferenciá-los ao nível mais profundo de classificação para efeito de controle social, a leitura de seu pertencimento à dimensão inclusiva gbe, já conhecida dos portugueses, seria pouco operacional. Na verdade, por motivos semelhantes, tampouco o termo mina cumpria nas matrículas um papel relevante como nação, pois foi utilizado apenas 11 vezes num total de 330 afro-ocidentais. Repetimos: naquele quadro demográfico e cultural em que os grupos da Costa da Mina formavam cerca de três quartos dos escravizados, era necessário buscar termos classificadores, "nações", mais específicos para singularizá-los. Essa dinâmica explicaria a aplicação do termo geja para designar a nação uma única vez nas matrículas. Contudo, mesmo que o escrivão tenha optado por descrever as origens por meio de nomenclatura mais pormenorizada, talvez até mais permeável a formas africanas de conceitualizar e narrar origens e pertencimento, ele continuava recorrendo ao termo geja em sua dimensão inclusiva e generalizante para detalhar as marcas corporais.

Esse processo estaria relacionado ao que ocorria na Bahia. Se a região dos diamantes estava inserida no perímetro gbe encabeçado por Salvador e Cachoeira, a nomenclatura que encapsulava a etnogênese jeje já era conhecida no Tejuco. Os comerciantes de quem compravam os escravos na Bahia certamente usavam o termo geja ou gege para nação e sabiam que nações específicas, como sabaru, ladá, cobú, courá etc., faziam parte daquele guarda-chuva classificador. Embora não integrasse a taxonomia das nações na região mineradora, geja enquanto marcador de pertencimento abrangente à origem gbe, passou por um processo de deslocamento e despontou, referenciado na experiência visual, no campo semântico das modificações corporais. Aquela era uma palavra que fazia

97 Parés, A formação do candomblé, pp. 63-100. 
sentido para a maioria dos africanos que viviam no distrito diamantino e para os traficantes e proprietários portugueses que tinham algum conhecimento sobre este universo cultural.

Argumentamos, então, que o emprego da palavra geja no Tejuco estaria ligado a um processo de tradução visual da sua potência enquanto descritor que codificava elementos culturais comuns que povos gbe partilhavam num contexto de intensos deslocamentos, rupturas e recomposições diaspóricas, como o uso da língua geral da mina, o culto aos voduns, e outras práticas culturais. Essas referências mediavam a interpretação visual que a sociedade colonial fazia das escarificações, dando sentido ao termo a ponto de utilizá-lo como palavra corrente do português empregado no aparato fiscal. A construção colonial que articulava o termo geja ("marcas gejas”, "sinais de gejas” etc.) seria uma codificação dessa dinâmica histórica que cruzava visualidade e léxico.

Se nossas hipóteses são plausíveis, esse não seria o único caso em que europeus estariam se apropriando de um vocábulo de origem africana na constituição da nomenclatura das marcas rituais. Keefer encontrou fenômeno parecido em Serra Leoa no começo do século XIX. Ali, um tipo específico de marca tornou-se um substantivo nos registros das embarcações apresadas pelas comissões mistas promovidas pela Inglaterra no combate ao tráfico, estabelecimento do sistema de trabalho de aprendizes e construção do colonialismo inglês. Analisando os registros que vão de 1808 a 1819, a autora notou que, ao lado da descrição de diversos detalhes das marcas (tatuagens e escarificações), os escrivães empregam o termo "purrah” para um conjunto específico de incisões. A etimologia do termo remontava a “Pっ lo”, nome nas línguas mandê e vai que designava a sociedade secreta que governava a iniciação dos meninos na vida adulta, regulava o comércio e atuava quase como governo regional nas imediações de Freetown e seu interior..$^{98}$ Portanto, a nomenclatura de uma sociedade iniciática que adotava as modificações corporais tornou-se, nos documentos, um substantivo para singularizar as

98 Keefer, “Group Identity, Scarification, and Poro”, p. 13. 
pessoas que saíam das embarcações. Por exemplo, do navio Esperanza, em 14 de maio de 1810, foi retirado Bua, "um homem de aproximadamente 23 anos, medindo 5 polegadas e quatro", com "triângulo Purrah em cada peito, dois pontos pretos nos lábios de cima”. 99 Outro, listado como o de número 1.171, também do período entre 1808 e 1812, chamado Pangay, tinha "marca longa na bochecha esquerda, espada tatuada em cada olho e Purrah nas costas". 100

A escassa literatura sobre as sociedades iniciáticas de ajuda mútua supraétnica na Costa da Mina não indica uma possível conexão entre geja e algum tipo de escarificação. Quando há menção a esses marcadores, são apontadas as bandas de tecido usadas na cabeça, como era o caso da sociedade supraétnica gbe gbe referida por Herskovits no Daomé do século XX. ${ }^{101}$ Dentre as várias sociedades da área mahi, descritas por Murila, tampouco há menção às marcas corporais. ${ }^{102} \mathrm{E}$, ainda que a palavra geja inicialmente tivesse seu significado vinculado a alguma sociedade iniciática, o fato inquestionável, argumentamos, é que no mundo afro-atlântico geja (e sua variação baiana gege/jeje) teria tido seu significado modificado e ampliado, tornando-se uma palavra associada principalmente aos grupos gbe falantes da área vodum, sobretudo na Bahia, e um descritor de marcas corporais na região diamantina, onde a maioria dos escravizados eram gbe.

99 Keefer, “Group Identity, Scarification, and Poro”, p. 16.

100 Keefer, “Group Identity, Scarification, and Poro”, p. 16.

101 Herskovits, Dahomey, an ancient West African kingdom, pp. 250-256.

102 Jessie Murila, A History of the Mahi Peoples from 1774-1920, Berkeley: University of California, 1984. 


\section{Considerações finais: a "gbeização" do léxico associado a detalhes das marcas rituais}

A consolidação e expansão diaspórica da semântica geja em suas várias facetas, como na matrícula de "Lucas de nação geja”, em 1752, na listagem das nações exportadas por Ajudá em 1766 (“ardras, minas e gejas”) e em todas as dezenas de vezes em que geja serviu para nomear pormenores de marcas corporais na região dos diamantes entre 1753 e 1754, demonstram que a administração colonial havia incorporado plenamente a palavra à língua portuguesa. Uma visão global de seu uso cotidiano revela que o termo passou a ser empregado inclusive no detalhamento de escarificações iorubás, e, para nossa surpresa, de marcas centro-africanas do Congo e de Angola. ${ }^{103}$

A preponderância gbe entre os africanos que viviam no distrito diamantino nunca eclipsou a presença de povos da África Centro-ocidental, que, somados, perfaziam 23\% das matrículas analisadas, 103 pessoas. ${ }^{104}$ Conforme o Quadro 1, eles eram categorizados como benguela, a maioria deles, angola, congo, ganguela, entre outros. ${ }^{105}$ A análise do inventário de

103 No caso iorubá, veja, por exemplo: Francisco Nagô, 24 anos, tinha “uma geja entre as duas sobrancelhas e outra em cada uma das faces e gejas em ambas as fontes ficando de tudo o mais liso da cara e uma berruga atras da orelha direita” (APM, CC 2.048, Matrícula de escravos, Tejuco, 1752). Na leitura do escrivão, os detalhes das marcas gejas dos nagôs tendem a ter configurações parecidas com aquelas dos adjas, localizam-se entre as sobrancelhas e nas fontes. Por isso, nossa ênfase nesta sessão são as cicatrizes centro-ocidentais pelo valor de seu contraste com os afro-ocidentais no teste das hipóteses que organizam o texto.

104 Em finais da centúria, os dados de registros de batismos sistematizados por Júnia Furtado indicam uma importante presença de povos da Costa da Mina na região. Júnia Furtado, "Quem nasce, quem chega: o mundo dos escravos no Distrito Diamantino e no arraial do Tejuco” in Júnia F. Furtado e Douglas Cole Libby (orgs.), Trabalho livre, trabalho escravo? Brasil e Europa, séculos XVIII e XIX (São Paulo: Annablume, 2006), v. 1, pp. 223-250.

105 O grupo mais expressivo dentre eles são os benguela (termo aplicado a 51 pessoas). Com base no trabalho de Candido, poderíamos inferir que essa presença saliente estivesse relacionada à penetração dos portugueses nas terras altas (highlands) do continente, a cerca de $300 \mathrm{~km}$ da costa, por meio de uma série de alianças com os sobas de Kakonda, Kabiunda e Kabunda entre 1730 e 1750. Os efeitos disruptivos desses eventos provavelmente levaram ao aumento do número de pessoas deportadas pelo 
suas cicatrizes rituais nos permite testar os limites das hipóteses sobre a influência adja-gbe na formação do campo semântico das escarificações e as nuances de seu processo de incorporação ao léxico dos documentos fiscais.

As gejas que aparecem nas matrículas de pessoas centro-africanas estão ligadas a incisões com algumas características básicas. Quanto à textura, as escarificações tendem a ser "levantadas”, possivelmente queloidais; e quanto à extensão, algumas são grandes e outras pequenas, sem maiores especificações. Em geral, tendem a incidir menos na face, "liso da cara”, e mais nos peitos e abdomens. Miguel, de nação Congo, de 29 anos, era "liso da cara e pouco picado na barba, e uma geja levantada no peito”, foi avaliado em $230 \mathrm{mil} .{ }^{106}$ Manoel Ganguela, de 29 anos, era “liso da cara com uma cicatriz no canto da testa da parte esquerda correndo pela cabeça e o braço direito com várias gejas levantadas e o peito todo cheio das mesmas gejas grandes avaliado em 170.000”. ${ }^{107}$ Antônio Benguela, 25 anos, era "liso da cara, com dois sinais de gejas no peito direito, estatura comprido". ${ }^{108}$ João Benguela, de 28 anos, era "liso da cara, com falta de dois dentes grandes de cima e os de baixo aguçados, com uma geja no peito direito e o esquerdo picado”. ${ }^{109}$ Manoel Ganguela, de 26 anos,

porto de Benguela. Cf. Mariana Candido, An African Slaving Port and the Atlantic World: Benguela and Its Hinterland, Cambridge: Cambridge University Press, 2013, p. 99. Os outros descritores centro-africanos são também bastante genéricos sobretudo a nação angola - e encobrem vários povos embarcados principalmente em Luanda com destino ao Rio de Janeiro, cf. Lucilene Reginaldo, Os rosários dos angolas: irmandades de africanos e crioulos na Bahia setecentista, São Paulo: Alameda, 2011, p. 185. Miller afirma que no século XVI os luso-brasileiros definiam Angola como a "região ngola a kiluanje, sob o domínio de governantes africanos ao longo do meio do rio Cuanza”. Posteriormente, "os representantes governamentais estabeleceram seu principal porto de escravatura em Luanda, no começo do século XVII, eles designaram as regiões interiores sujeitas ao seu controle militar como o 'Reino e conquista d'Angola'” - Joseph Miller, “África Central durante a era do comércio de escravizados, de 1490 a 1850” in Linda Heywood (org.), Diáspora negra no Brasil, São Paulo: Contexto, 2010, p. 39.

106 APM, CC 2.048, n. 149, fl. 75, Matrícula de escravos, Tejuco, 1752 (grifo nosso). 107 APM, CC 2.048, n. 254, fl. 127v, Matrícula de escravos, Tejuco, 1752 (grifo nosso). 108 APM, CC 2.048, n. 77, fl. 39, Matrícula de escravos, Tejuco, 1752 (grifo nosso).

109 APM, CC 2.048, n. 162, fl. 81v, Matrícula de escravos, Tejuco, 1752 (grifo nosso). 
“cara lisa e comprida com duas gejas pequenas na barriga”. ${ }^{110}$ Antônio Luanda, 22 anos, "fula e liso da cara, boca grande e beiços grossos e uma geja grande atravessada no peito”. ${ }^{111}$ Proporcionalmente, a ocorrência de marcas gejas nestas nações centro-africanas era muito baixa: aparecem em 3 benguelas de um grupo de 51 pessoas; em 2 congos de um grupo de 14; em 3 ganguelas de um conjunto de 7 pessoas e em ninguém das 20 pessoas da nação angola. Nestas poucas vezes em que as gejas foram atribuídas a escarificações que adornavam os rostos de pessoas centro-africanas, elas tendiam a se localizar sobretudo nas fontes. Joaquim Benguela, de 20 anos, era marcado "com quatro gejas na fonte direita, uma cicatriz pequena por cima da sobrancelha esquerda e duas cicatrizes no beiço de baixo". ${ }^{112}$ Manoel Ganguela, 22 anos, “com três gejas pequenas em cada fonte e picado entre as sobrancelhas, beiço vermelho." ${ }^{113}$ Nestes casos, os oficiais das matrículas poderiam estar adotando a nomenclatura normalmente aplicada a povos adjas como parâmetro para nomear detalhes possivelmente semelhantes que esporadicamente encontravam em escarificações inscritas na pele de pessoas cujas origens eram classificadas como congo, angola, ganguela e benguela. Mas esta tendência convive nos registros com o uso genérico do termo geja para incisões localizadas fora do rosto. Sua possível característica, quando localizadas no peito ou nos braços, poderia ser o efeito visual queloidal, “levantadas”, mas nas matrículas elas aparecem também sem qualquer especificação.

De todo modo, os vestígios presentes nos exemplos referentes a pessoas da África centro-ocidental sugerem que geja, um termo que despontou no mundo atlântico como uma nação associada à deportação massiva de pessoas falantes de línguas gbe pelos portos da Costa da Mina, sobretudo Ajudá, passou por uma dilatação de seu significado.

110 APM, CC 2.048, n. 165, fl. 83, Matrícula de escravos, Tejuco, 1752 (grifo nosso). 111 APM, CC 2.048, n. 291, fl. 146, Matrícula de escravos, Tejuco, 1752 (grifo nosso). 112 APM, CC 2.048, n. 377, fl. 189, Matrícula de escravos, Tejuco, 1752 (grifo nosso). 113 APM, CC 2.048, n. 365, fl. 183, Matrícula de escravos, Tejuco, 1752 (grifo nosso). 
Sem que isso acontecesse de forma coesa ou linear, passou a designar também elementos dos desenhos formados pelas modificações corporais de grupos centro-africanos. Podemos concluir que teria havido uma transformação do sentido da palavra geja até o ponto de se estabilizar como substantivo do campo semântico das marcas corporais, independentemente da procedência na África. Houve uma “gbeização” das possibilidades de textualizar a leitura que se fazia dos efeitos visuais das cicatrizes. Esse uso mais generalizante convivia de forma descontínua com a tendência a empregar o termo gejas na listagem de conjuntos mais específicos de desenhos com dois sinais paralelos presentes nas têmporas de grupos ladá e, em menor proporção, ouemé.

Por trás da banalização da palavra geja na produção do rol de adornos inscritos na pele de grupos da África centro-ocidental estava a preponderância esmagadora de grupos gbe na região dos diamantes. A história de sua presença marcante em Minas Gerais desde o início da mineração acabou ficando plasmada no campo semântico das marcas rituais.

A análise das fontes não permite uma explicação que siga um fluxo passo a passo das metamorfoses dos significados de geja, talvez porque o próprio caráter fragmentário e movediço das informações seja uma metáfora que encapsula a complexidade da experiência diaspórica. Aquele era um mundo muito instável e permeado de arranjos possíveis e muitas vezes provisórios. De qualquer forma, quando vistas num conjunto mais amplo, notamos importantes conexões que dão pistas contundentes sobre o pano de fundo em que o fenômeno ocorreu: a ampliação da semântica de geja aconteceu em um quadro marcado, repetimos uma última vez, pela predominância gbe. Foi sua densa experiência histórica no circuito atlântico que conectava Minas Gerais à Baía do Benim que mediou a ampla difusão do termo geja e sua explosão no aparato textual do sistema de controle social e arrecadação fiscal diamantino. Seu uso codificava, portanto, a tradução visual daquele processo histórico formado por linhas de continuidades e descontinuidades tecidas pela população africana, traficantes, agentes coloniais e senhores de escravos. Ao posicionar a 
dimensão visual das modificações corporais no centro da análise, este artigo oferece um ângulo novo para compreendermos a formação história da diáspora jeje no Brasil.

Recebido em 3 set. 2020

Aprovado em 24 nov. 2020

doi: 10.9771/aa.v0i63.38662 
Este artigo analisa os impactos da presença dos grupos de línguas gbe na formação do léxico empregado no detalhamento das cicatrizes rituais da população africana presente no distrito diamantino da capitania de Minas Gerais em meados do século XVIII. O enfoque é dado sobre o processo histórico de difusão do termo "geja", explorando tanto os seus significados ligados a padrões específicos de escarificações como o seu uso generalizado para marcas corporais africanas, independentemente da origem étnica. Examina-se a sua emergência como índice de uma cadeia mais ampla de significados atrelados à etnogênese jeje em um contexto de grande concentração urbana de povos da Costa da Mina.

Nação jeje | Diáspora africana | Gejas | Escarificações

"With Two GeJas on EACh TeMple":

SCARIfication AND the Process of Visual Translation

in the JeJe Diaspora of 18th Century in Minas Gerais

Considering the visual culture of the African diaspora, this article analyzes the effects of the presence of Gbe language groups in the formation of the lexicon used in detailing the ritual scarification of the African population present in the diamond district of the captaincy of Minas Gerais in the eighteenth century. It focuses on the historical process of spreading the term geja, exploring both its meanings linked to specific patterns of scarification and its widespread use for African body markings in general. Its emergence is examined as an index of a broader chain of meanings connected to the Gbe ethnogenesis in a context of great urban concentration of people from Costa da Mina.

Jeje Nation | African Diaspora | Gejas | Scarification 